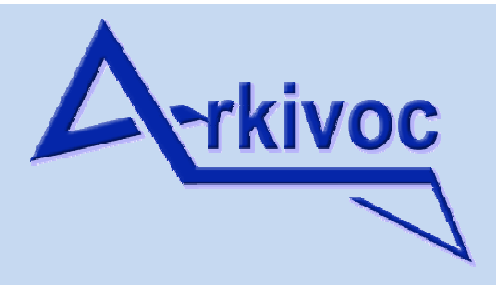

Archive for

Organic Chemistry
The Free Internet Journal

for Organic Chemistry
Review

Arkivoc 2018, part 1, 0-0

to be inserted by editorial office

\title{
Microwave-promoted synthesis of cyclic imides
}

\author{
Isabel A. Perillo, María S. Shmidt, Sofía C. Prieto, and María M. Blanco*
}

Universidad de Buenos Aires, Facultad de Farmacia y Bioquímica, Departamento de Química Orgánica. Junín 956 CABA (1113), Buenos Aires, Argentina

E-mail: mblanco@ffyb.uba.ar

Received mm-dd-yyyy

Accepted mm-dd-yyyy

Published on line mm-dd-yyyy

Dates to be inserted by editorial office

\section{Abstract}

Cyclic imides have been extensively investigated because of the wide range of biological activities they exert, as well as due to their importance as synthetic intermediates. Nowadays, focus has been placed on this important class of compounds for their potential new applications, especially in the area of pharmaceutical chemistry. Consequently, the strategies applied for the synthesis of these compounds have attracted considerable attention. Several innovative methodologies have been developed to obtain and functionalize this class of compounds. The use of microwave heating, which is an environmentally harmless strategy, has been making successful inroads in many chemistry areas, such as organic synthesis. Herein we present an update of the microwave-promoted methods for the synthesis of cyclic imides.

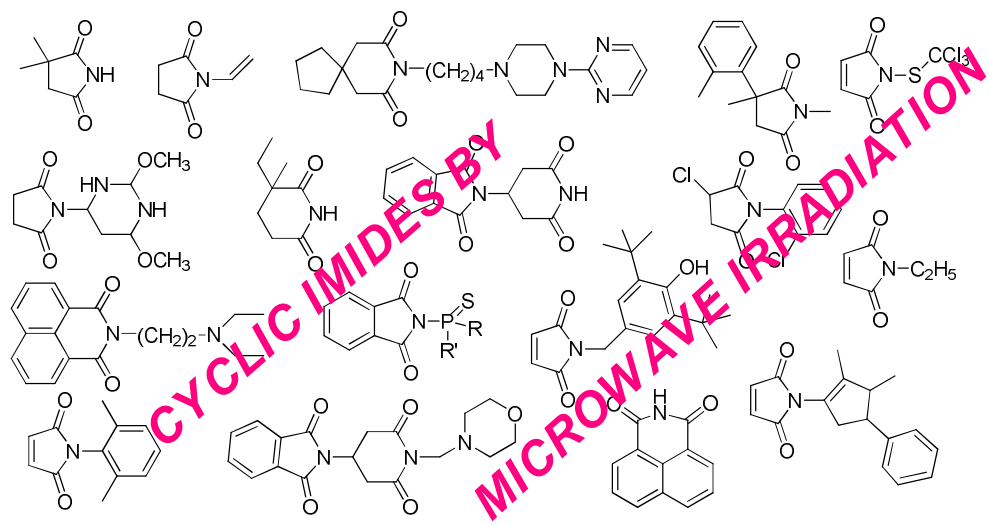

Keywords: Cyclic imides, synthesis, N-alkylation, microwaves, green chemistry 


\section{Table of Contents}

1. Introduction

1.1 Most relevant synthesized imides

1.2 Microwave-assisted organic reactions and "Green Chemistry"

2. Synthesis of $\mathrm{N}-$ Unsubstituted Imides

2.1 From anhydrides or diacids

2.1.1 Employing ammonia or ammonium salts

2.1.2 Employing amides and thioamides

2.1.3 Employing urea and thiourea

2.1.4 Employing other reagents

2.2 Other methods

3. Synthesis of N-Substituted Imides

3.1 Condensation of anhydrides with amines without isolation of the amic acid intermediates

3.1.1 Reactions employing solvents

3.1.2 Solvent-free reactions

3.2 Amic acid cyclizations

3.3 N-Alkylation of imides with halogenated compounds

3.3.1 Reactions in solution

3.3.2 Solvent-free reactions

4. Acknowledgements

References

\section{Introduction}

\subsection{Most relevant synthesized imides}

Imides are diacyl derivatives of ammonia or a primary amine. Among imides, cyclic imides derived from dicarboxylic acids are the most important representatives of this class. Particularly, derivatives of phthalimide $(\mathbf{1}, \mathrm{R}=\mathrm{H})$, maleimide $(2, R=H)$, succinimide $(3, R=H)$, glutarimide $(4, R=H)$ and naphthalimide $(5, R=H)$ have attracted the attention of researchers (Figure 1 ).<smiles>[R]N1C(=O)c2ccccc2C1=O</smiles>

1<smiles>[R]N1C(=O)C=CC1=O</smiles>

2<smiles>[R]N1C(=O)CCC1=O</smiles>

3<smiles>[R]N1C(=O)CCCC1=O</smiles>

4

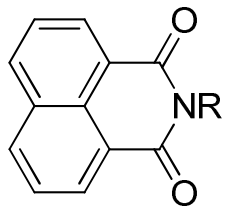

5

Figure 1

The capacity of imides to cross biological membranes in-vivo conferred by their hydrophobicity is well known. ${ }^{1}$ Due to their pharmacokinetic properties, derivatives of cyclic imides exhibit a wide range of biological properties. Cyclic imides have also a great number of applications in polymer and synthetic chemistry. 
Particularly, phthalimide derivatives (1) constitute a prominent class of compounds displaying many biological properties, including antimicrobial, antimalarial, antiviral, anticonvulsant and anxiolytic. ${ }^{2-5}$ Moreover, many imides exert antitumor, antiangiogenic and anti-inflammatory effects, ${ }^{2-4,6}$ among others. ${ }^{7-9}$

Not only are phthalimide derivatives used as synthetic intermediates to prepare primary amines and agricultural pesticides but also in the preparations of preservatives, pigments and pharmaceuticals. ${ }^{10-13}$ The phthaloyl group is well known for its protective capacity of the primary amines of many compound families, particularly aminoacids, peptides, aminoglycosides and ?-lactam antibiotics. ${ }^{14}$ In addition, phthalimides have also been used as key components in materials and polymers, ${ }^{15,16}$ as catalysts ${ }^{17}$ and fluorescent probes. ${ }^{18,19}$

Maleimides (2) are a prominent class of substrates suitable for biological, pharmacological and chemical applications. The activity of maleimides as antifungal, antimicrobial and insecticide compounds has been reported..$^{2,20-24}$ These compounds have also proved to have analgesic and antispasmodic activities. ${ }^{2}$ They can also form conjugates with peptides and antibodies and act as enzyme inhibitors. ${ }^{21-25}$

The maleimide moiety can be used as a versatile synthesis platform due to its Michael accepting ${ }^{26-29}$ and dienophilic nature, as well as its dipolarophile characteristic in 1,3-dipolar cycloadditions. ${ }^{30-33} \mathrm{~A}$ recent review shows the importance of maleimides as building blocks for the synthesis of polymers. ${ }^{34}$

Substituted succinimides (3) such as ethosuximide, methosuximide or phensuximide, among others (Figure 2), have strong anticonvulsant activity. ${ }^{2,35,36}$ This type of imides, also have a variety of biological and pharmaceutical uses such as CNS depressant, analgesic, antitumor, cytostatic, anorexigenic, nerve conduction blocking, antispasmodic, bacteriostatic, muscle relaxant, hypotensive, antibacterial, antifungal and antitubercular. ${ }^{2,37,38}$ Chiral succinimides with antifungal activity have shown higher activity than the corresponding racemic mixtures, thus opening new avenues for the development of highly active drugs containing 3- and 3,4substituted chiral succinimides. ${ }^{39}$

\begin{tabular}{|c|c|c|c|c|}
\hline & & $\mathrm{R}^{1}$ & $\mathrm{R}^{2}$ & $\mathrm{R}^{3}$ \\
\hline & Ethosuximide & $\mathrm{H}$ & $\mathrm{C}_{2} \mathrm{H}_{5}$ & $\mathrm{CH}_{3}$ \\
\hline & Methosuximide & $\mathrm{CH}_{3}$ & $\mathrm{C}_{6} \mathrm{H}_{5}$ & $\mathrm{CH}_{3}$ \\
\hline$R^{3}$ & Phensuximide & $\mathrm{CH}_{3}$ & $\mathrm{C}_{6} \mathrm{H}_{5}$ & $\mathrm{H}$ \\
\hline
\end{tabular}

\section{Figure 2}

Glutarimide derivatives (4) have a hydrophobic nature, which accounts for their antibacterial and antifungal potencies. ${ }^{2,40}$ The antitumoral and analgesic effects, as well as the effect on the CNS have been reported. ${ }^{2}$ The glutarimide moiety is present in alkaloids, such as filantimide, julocrotine and streptimidone, among others. ${ }^{41}$ These alkaloids exhibit interesting biological activities, mainly antimicrobial.

Thalidomide (Figure 3), which presents a glutarimide moiety, was first synthesized as an antihistaminic drug and introduced as a sedative drug in 1956. It was widely used to treat nausea during pregnancy; however, the drug was withdrawn from the market because of its high teratogenicity. Due to its immunomodulatory properties, thalidomide was then employed for the treatment of leprosy and multiple myeloma. The exploration of the anti-inflammatory, antiangiogenic, anticancer and immunomodulatory activities of thalidomide has prompted the synthesis and study of thalidomide analogs such as lenalidomide and pomalidomide. ${ }^{6,42-45}$ It has also been used in AIDS therapy. ${ }^{46}$ 


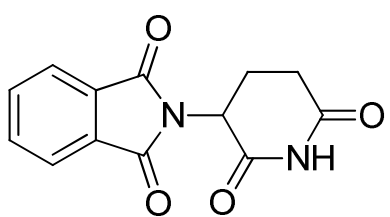

Thalidomide

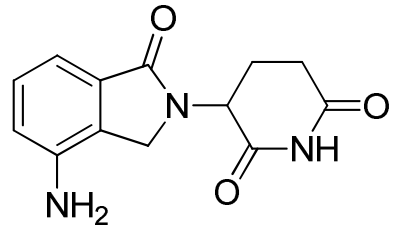

Lenalidomide

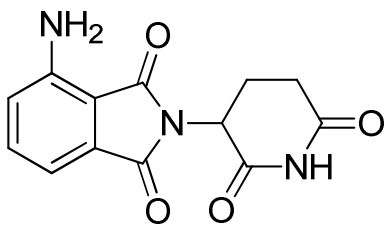

Pomalidomide

\section{Figure 3}

The high antitumor activity of 1,8-naphthalimides (5) is due to their effective DNA-intercalating and apoptosis induction capacities. ${ }^{47-49}$ Most 1,8 naphthalimides have many biological activities, such as anticancer against murine antiviral, analgesic, local anesthetic, antitrypanosomal and serotonin 5-HT3 and 5-HT4 receptor antagonist. ${ }^{48}$ Many naphthalimide derivatives are fluorescent, being employed in fluorescent cell biology imaging techniques. ${ }^{47}$

Heterocyclic imides, especially phthalimide analogs in which the benzene nucleus is replaced by a heterocyclic ring, have been extensively studied (Figure 4). In particular, $N$-substituted derivatives of 3,4pyridinedicarboximide (cinchomeronimide, 6 ) have proved to exhibit potent analgesic activity, superior to that of acetylsalicylic acid, and some of them are non-toxic. ${ }^{50-53} \mathrm{~N}$-Aryl substituted derivatives of 2,3pyridinedicarboximide (quinolinimide, 7) and 2,3-pyrazinodicarboximide (8) have shown high cytotoxic activity with high DNA affinity and capacity to induce apoptosis. ${ }^{54}$

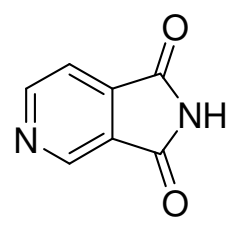

6<smiles>O=C1NC(=O)c2ncccc21</smiles>

7<smiles>O=C1NC(=O)c2nccnc21</smiles>

8

\section{Figure 4}

\subsection{Microwave-assisted organic reactions and "Green Chemistry"}

The development of environmentally harmless and efficient synthetic protocols is still a central goal in chemistry research. The well-known microwave (MW) heating technique employed for cooking foods has made inroads in several chemistry fields such as nanotechnology ${ }^{55,56}$ and organic synthesis (microwaveassisted organic synthesis, MAOS). ${ }^{55,57-61}$ Under $\mathrm{MW}$ irradiation conditions, organic reactions can be accelerated and product selectivities can be achieved by choosing appropriate MW parameters, thus offering several advantages over conventional heating, such as rapid and deep internal heating, high temperature homogeneity, and selective heating. Some of the novel areas in which MAOS has been applied are solid-phase synthesis, biopolymer synthesis, proteomics, parallel processing in microwave reactors and automated library generation by means of sequential microwave irradiation methods. ${ }^{62}$

Since the first reports in 1986, ${ }^{63,64}$ the use of the MW heating technique has become an essential tool in all areas of organic synthesis. The use of $\mathrm{MW}$-assisted reactions in organic chemistry has reduced the cost, and time and energy requirements. Employment of this novel strategy has given rise to the so-called "Green Chemistry", and the application of such strategy is now fostered to minimize the use of nonrenewable resources as well as polluting solvents, which are known to generate secondary toxic products, and to reduce the emission of harmful gases. ${ }^{62}$ In the context of the Green Chemistry, ${ }^{65,66}$ solvent-free ${ }^{67,68}$ and water-mediated ${ }^{69-71} \mathrm{MW}$-assisted reactions acquire a relevant role. 
Initially, household MW devices were used in organic synthesis at the laboratory scale. Some modifications of domestic MW ovens, such as the introduction of condensers, have been developed. These ovens (with limited power 800-1000 W) are characterized by a non-homogeneous distribution of the electric field caused by reflections from the metallic walls of the oven. Currently, two types of MW reactors are used in the laboratory: multimode MW reactors, (with a heterogeneous distribution of electric field inside the cavity) and monomode microwave reactors (with a homogeneous distribution). Nowadays, reactors have a built-in external reaction vessel with compressed air for the simultaneous cooling while being irradiated with MW. Thus, more energy can be directly applied to the reaction mixture (Enhanced Microwave Synthesis, EMS). The use of single mode MW reactors in continuous flow reactions, capable of operating at elevated temperatures and pressures, are gaining popularity. ${ }^{72,73}$ The $\mathrm{MW}$-induced flow chemistry has also been adapted to the use of microreactors. ${ }^{74}$

MW-induced chemistry has been used in combination with ultrasound (US), either in a sequential or a simultaneous fashion. Synergic or additive effects resulting from the combination of both strategies have been widely demonstrated. ${ }^{73,75-77}$

$\mathrm{MW}$-assisted organic reactions are classified into two categories: $\mathrm{MW}$-assisted reactions in which solvents are used and those that proceed under solvent-free conditions. In the case of the MW-assisted reactions in which solvents are employed, the reactants are usually dissolved in the solvent, which often couples effectively with MW, thus acting as the energy transfer medium (Solution Phase Chemistry, SPC). On the other hand, reactions occurring under solid state conditions using polymeric supports (Solid Phase Organic Synthesis, SPOS) $)^{57,78}$ have gained increasing attention in combinatorial chemistry. ${ }^{57,79}$

MW-assisted solvent-free organic synthesis (MASFOS) can be carried out under three different conditions, i.e., reactions using neat reactants, reactions using solid-liquid phase transfer catalysis (PTC) and reactions using solid mineral supports. When neat reactants are used, at least one of the reactants should normally be liquid at the reaction temperature. Under such conditions, either the solid is partially soluble in the liquid phase or the liquid is adsorbed onto the surface of the solid with the reaction occurring at the interface. Alternatively, both reactants can be solids. Usually, these reactants melt before the reaction takes place. The use of PTC is specific for anionic reactions, as it involves an "anionic activation" step, as is the case of reactions involving tetra-alkylammonium salts. Free-solvent reactions can also be carried out by adsorbing the reactants onto solid supports like silica and alumina, which are essentially inorganic oxides.

Taking into account the biological importance of imides and the great deal of attention that the use of green synthetic methods has attracted over the last years, we present an update of the methods that use MW as an alternative energy source for the synthesis of these compounds.

\section{Synthesis of $\mathbf{N}$-Unsubstituted Imides}

\subsection{From anhydrides or diacids}

The most common method for the preparation of $\mathrm{N}$-unsubstituted imides involves the condensation of either the anhydride or the dicarboxylic acid with an aminating agent. The reaction proceeds through the generation of amic acid intermediates which then undergo cyclization to form the imide (Scheme 1). 


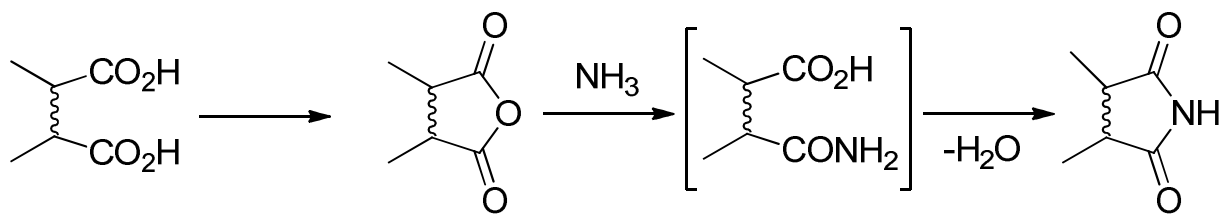

Scheme 1

Conventional synthetic techniques employing ammonium salts, urea, amides and other agents have been adapted to MAOS. The synthesis strategies described below have better performance, are less timeconsuming and are simple to work-up when compared with conventional heating.

2.1.1 Employing ammonia or ammonium salts. Aqueous solutions of ammonia have proved suitable for the synthesis of phthalimide ${ }^{80}$ and quinolinimide. ${ }^{81}$ For instance, Perillo et al. have studied the reaction of quinolinic acid or its anhydride with aqueous ammonia or with a reagent capable of generating ammonia in situ, such as urea, acetamide or ammonium carbonate, under MW irradiation in a modified domestic oven. The highest yields were obtained with $28 \%$ aqueous ammonia (Scheme 2 ).

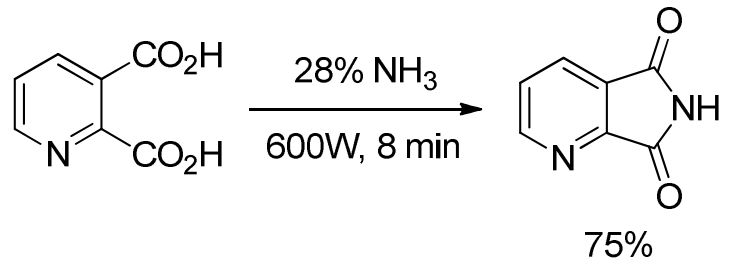

\section{Scheme 2}

Hijji et al. have synthesized a variety of cyclic imides using ammonium chloride $\left(\mathrm{NH}_{4} \mathrm{Cl}\right)$, and 4-N,Ndimethylaminopyridine (DMAP) or ammonium acetate $\left(\mathrm{NH}_{4} \mathrm{OAC}\right)$ under $\mathrm{MW}$ irradiation in both monomode and conventional microwave ovens. ${ }^{82}$ Several substituted succinic anhydrides used as reactants were synthesized efficiently through Diels-Alder addition reactions of maleic anhydride with 1,3-cyclohexadienes (Scheme 3). When maleic anhydride was employed, polymeric by-products were obtained instead of maleimide.

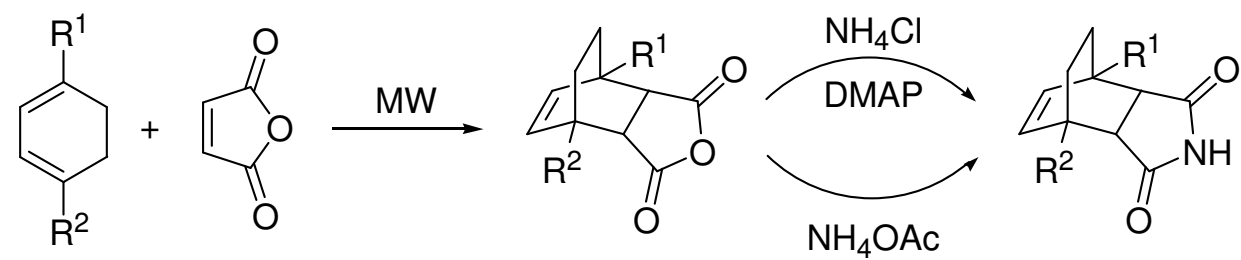

$50-98 \%$

\section{Scheme 3}

2.1.2 Employing amides and thioamides. Amides serve both as aminating reagents and solvents. Their polar nature makes them suitable for the use with MW. Peng and Kacprzak have reported the simple high-yielding and rapid MW-assisted synthesis of a wide array of aromatic mono- and bis-imides using formamide. ${ }^{83,84}$ In these reactions, small quantities of formamide are required. Reactions were performed in a domestic oven operating at 600-700 W for 2.5-5 min. Examples of the synthesized bis-imides are shown below (Figure 5). ${ }^{84}$ 
<smiles>O=C1NC(=O)c2cc(-c3ccc4c(c3)C(=O)NC4=O)ccc21</smiles><smiles>CC(C)(C)OC(=O)c1ccc2c(c1)C(=O)NC2=O</smiles><smiles>O=C1NC(=O)c2ccc3c4c(ccc1c24)C(=O)NC3=O</smiles>

\section{Figure 5}

Attempts to obtain maleimide from formamide have been unsuccessful, since in all cases polymeric byproducts were obtained instead of the desired imide. ${ }^{83}$ However, maleimide was obtained through a one-pot conversion of anhydrides in solid phase $(\mathrm{NaCl})$ by using thioacetamide. ${ }^{85}$

2.1.3 Employing urea and thiourea. Urea and thiourea are the most widely used reagents for imidation reactions (Scheme 4). As a rule, thiourea has proved to be more efficient than urea for the synthesis of $\mathrm{N}$ unsubstituted imides.

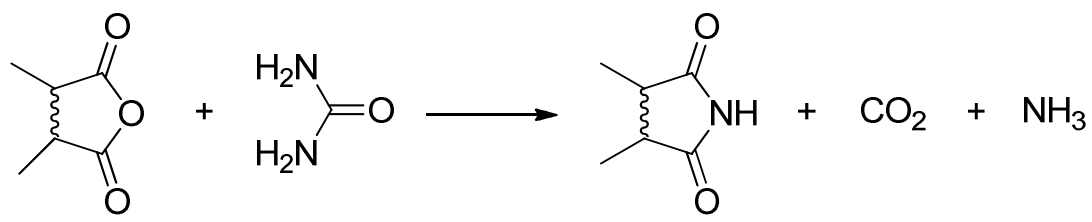

\section{Scheme 4}

Several conditions have been described for the imidation reactions using these reagents. The results are evidently influenced by the nature of the reagents and the equipment used. Thus, in some cases the presence of solvents such as DMF is essential, ${ }^{84}$ though in some cases, only a few drops of DMF are required. ${ }^{86}$ Solventfree reactions have also been reported. ${ }^{87}$ In particular, Seijas ${ }^{88}$ has reported the direct synthesis of thalidomide in high yield through the MW irradiation (domestic oven) of $N$-phthaloyl-L-glutamic acid in the presence of either urea or thiourea (Scheme 5).
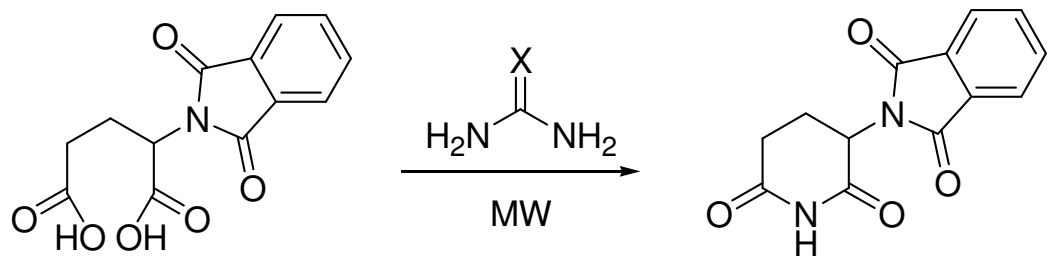

$$
\begin{aligned}
& X=O, 63 \% \\
& X=S, 85 \%
\end{aligned}
$$

\section{Scheme 5}

Taherpour et al. $^{89}$ have described the solvent free one-pot MW-assisted synthesis of phthalimides and maleimides from cyclic anhydrides using $\mathrm{KBr}$ as solid phase and urea or thiourea as reagents.

2.1.4 Employing other reagents. Potassium cyanate or sodium thiocyanate have been used in neutral media (DMF) to obtain a variety of unsubstituted imides in good to excellent yields. ${ }^{90}$ The reaction did not proceed under solvent-free conditions. The cyanate proved to give higher yields than the thiocyanate, probably due to the stronger nucleophilicity of the nitrogen atom present in the former reagent. The proposed reaction mechanism is shown in Scheme 6. 


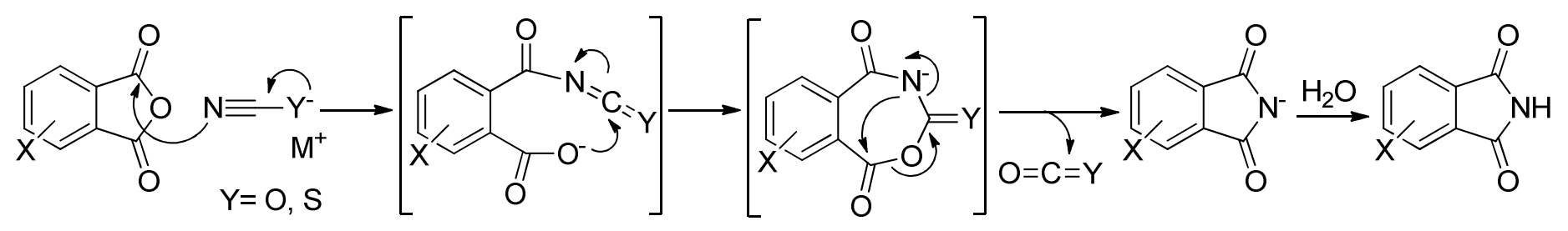

\section{Scheme 6}

A number of unsubstituted cyclic imides have been synthesized from a mixture of cyclic anhydrides, hydroxylamine hydrochloride and 4-N,N-dimethylaminopyridine (DMAP) as base catalyst in sealed vials under MW irradiation. ${ }^{91}$ This synthesis rendered the unsubstituted cyclic imides in high yields instead of the predicted $\mathrm{N}$-hydroxy derivatives which were found to be the minor products. The production of unsubstituted cyclic imides appeared to be enhanced by higher temperatures and longer reaction times. Good yields were obtained in both multimode and monomode MW ovens (Scheme 7).

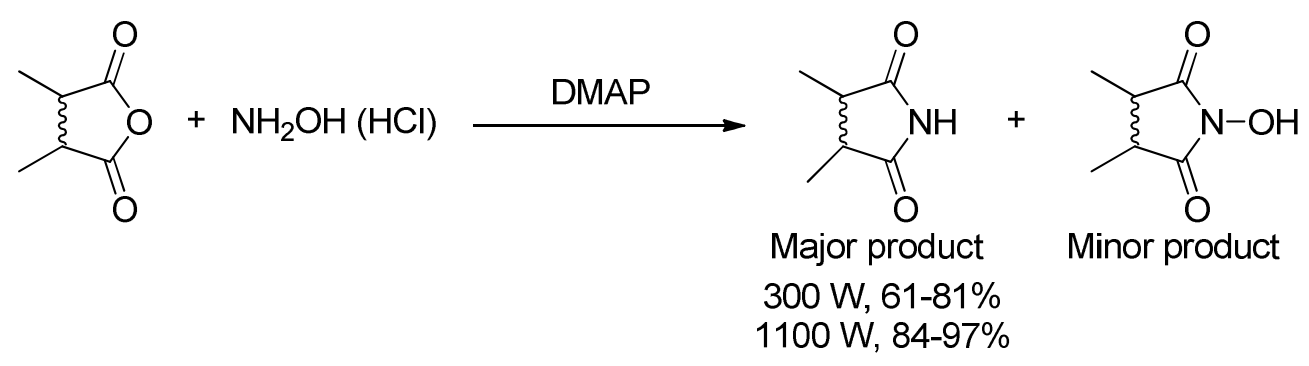

\section{Scheme 7}

\subsection{Other methods}

Taherpour et al. have reported the conversion of $\mathrm{N}$-unsubstituted lactams to cyclic imides by oxidation, with an oxidative agent such as peracetic acid or tert-butylhydroperoxide and a transition metal salt (manganic II or III) under MW irradiation. ${ }^{92,93}$ Thus, 2-pyrrolidinone, $\delta$-valerolactam and $\gamma$-caprolactam were converted in good yields into succinimide, glutarimide and adipimide, respectively (Scheme 8).

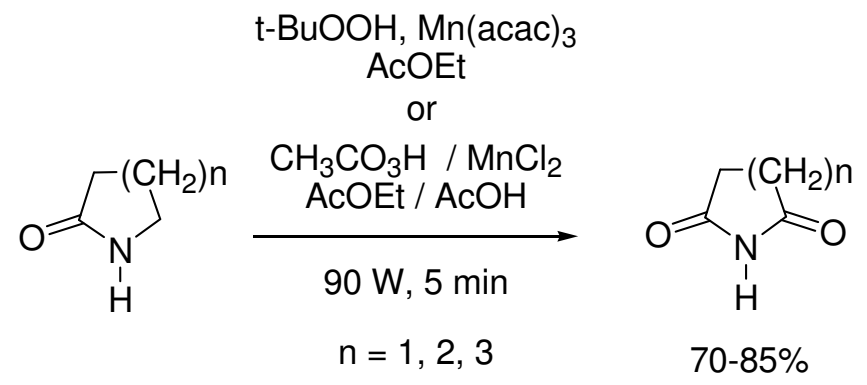

\section{Scheme 8}

Alterman et al. have applied the carbonylation-cyclization method for phthalimide synthesis using 2bromobenzamide as starting product and $\mathrm{Mo}(\mathrm{CO})_{6}$ as $\mathrm{CO}$ source (Scheme 9). ${ }^{94}$ 
<smiles>NC(=O)c1ccccc1Br</smiles>

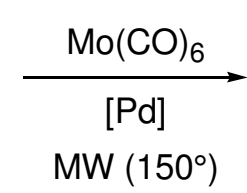

$\operatorname{MW}\left(150^{\circ}\right)$<smiles>O=C1NC(=O)c2ccccc21</smiles>

$70 \%$

\section{Scheme 9}

\section{Synthesis of $\mathbf{N}$-Substituted Imides}

\subsection{Condensation of anhydrides with amines without isolation of the amic acid intermediate}

It is generally accepted that imidation involves two steps: aminolysis of the anhydride giving amic acids and subsequent dehydration. This method is limited to the use with amines which are stable under dehydration conditions (Scheme 10). This reaction has been performed by different methodologies compatible with MW.

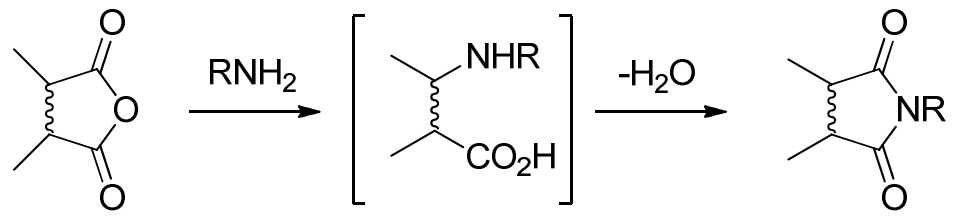

\section{Scheme 10}

3.1.1 Reactions employing solvents. The first antecedent of this type of MW-promoted reaction is that reported by Bose et al. ${ }^{95}$ who have developed a technology known as MORE (Microwave-Assisted Organic Reaction Enhancement). An Erlenmeyer flask covered with a watch glass or funnel is used as the reaction vessel. For the reaction medium, a polar solvent with a boiling point that is $20-30{ }^{\circ} \mathrm{C}$ higher than that of the desired reaction temperature is selected. The reaction mixture is then rapidly heated under MW irradiation. Thus, using a domestic MW oven, the authors prepared phthalimidoacetic acid from phthalic anhydride and glycine in DMF in the presence of triethylamine (TEA) as catalyst (Scheme 11).

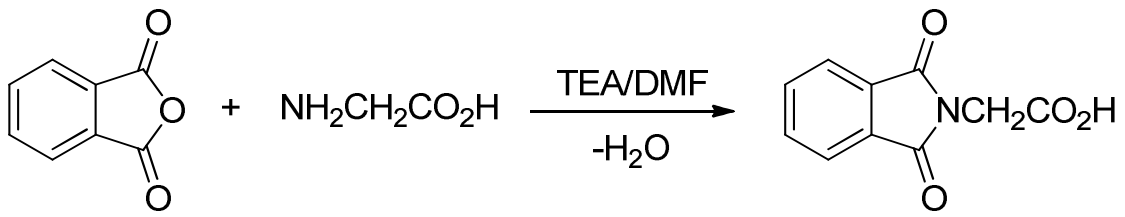

\section{Scheme 11}

A substantial difference between the reaction with MW in DMF (5-8 min) and the classical one carried out in toluene $\left(1.5 \mathrm{hr}\right.$ ) was found. ${ }^{95}$ The higher rate of the MW-promoted reaction was attributed to a specific activation of the molecules by the MW (non-thermal effect). This reaction was re-examined by Westaway and Gedye, ${ }^{96}$ who have found that the reaction rate was actually the same when either conventional or MW heating were applied, using DMF at the same temperature. Hence, the authors concluded that the rate increase observed by Bose et al. could be attributed to the change of solvent from toluene to DMF, which allowed working at higher temperatures. Based on the simplicity of the methodology developed by Bose et al., 
the reaction of phthalic anhydride with glycine was selected to test the suitability of MW acceleration in an undergraduate teaching laboratory setting. ${ }^{97}$

The tetrachlorophthaloyl (TCP) group has been used as an aminoacid protecting group in the MORE methodology. Bose et al. ${ }^{98}$ have described the synthesis of tetrachlorophthalimidoacetic acid as an intermediate in the synthesis of $\alpha$-amino- $\beta$-lactams. More recently, Bardaji et al. ${ }^{99}$ have tested the stability of the TCP function in comparison with the standard Fmoc and Boc removal conditions as well as to TFA cleavage treatments, demonstrating that the method is suitable for solid phase synthesis of peptides.

In some cases, the amount of solvent can be reduced to a few drops, necessary only to moisten the reaction mixture, thereby obtaining high quantities of pure cyclic imides in a matter of hours. ${ }^{80,86,100,101}$

Although one advantage of DMF as solvent is its capability to retain water formed during the course of the reaction, hence avoiding the need for a water separator, ${ }^{102}$ the employment of molecular sieves can improve the results as is the case of the synthesis of quinolinimides from quinolinic anhydride. ${ }^{81}$

Other neutral, acid or basic solvents with different polarity, have proved useful. Chorell has synthesized $\mathrm{N}$ substituted phthalimides from phthalic acids and amines in one step employing acetonitrile, acetic acid or pyridine. ${ }^{103}$ The method is general and good yields were obtained even when anilines with electron acceptor groups and sterically hindered amines were employed.

Recently, a series of bispyromellitimides, ${ }^{104}$ which is an important class of substrates in polymer chemistry, were synthesized through the condensation of pyromellitic dianhydride (PMD) with anilines in glacial acetic acid and few drops of pyridine and using MW irradiation in a modified domestic oven (Scheme 12).

2<smiles>Nc1c[R]ccc1</smiles>

(1)<smiles>O=c1oc(=O)c2cc3c(=O)oc(=O)c3cc12</smiles>

PMD

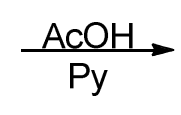

$\mathrm{R}=\mathrm{CO}_{2} \mathrm{H}, \mathrm{H}, 4-\mathrm{Cl}$, 3-Cl, 4-Br, 4-OH, $4-\mathrm{NO}_{2}, 4-\mathrm{SO}_{3} \mathrm{H}$<smiles>[R]c1ccccc1NC(=O)c1cc(C(=O)O)c(C(=O)Nc2ccccc2)cc1C(=O)O</smiles>

$400 \mathrm{~W}$ 8-15 $\min$<smiles>[R]CCCc1ccccc1-n1c(=O)c2cc3c(=O)n(-c4ccccc4)c(=O)c3cc2c1=O</smiles>

\section{Scheme 12}

The use of water as a green solvent has been successful. In 2001, Ondrus et al. described a new route for the synthesis of novel chiral maleimides. A cheap and readily available exo-Diels-Alder adduct of furan and maleic anhydride reacted with ? -amino acids in water under $\mathrm{MW}$ irradiation conditions, with the release of furan to give maleimides in good to excellent yields (Scheme 13). ${ }^{105}$ 


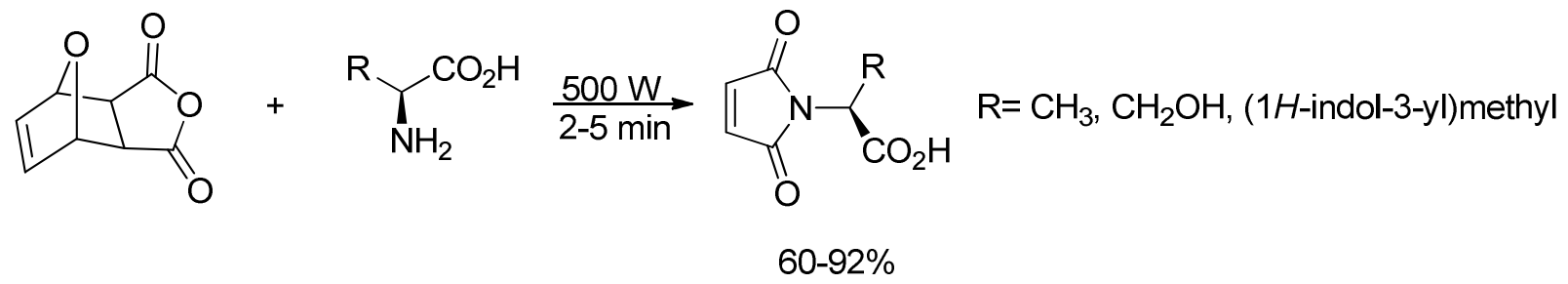

\section{Scheme 13}

Kočevar et al. ${ }^{106}$ have described the transformation of fused succinic anhydride derivatives of the bicyclo[2.2.2] oct-2-ene system with various amines under MW irradiation conditions. In aqueous suspensions, the reaction of an acetyl-containing derivative yielded chemoselectively succinimide derivatives with the acetyl group remaining unchanged. Conversely, the application of neat reaction conditions with a small amount of a liquid additive (toluene) yielded succinimide derivatives with the acetyl moiety transformed into an imine group (Scheme 14).
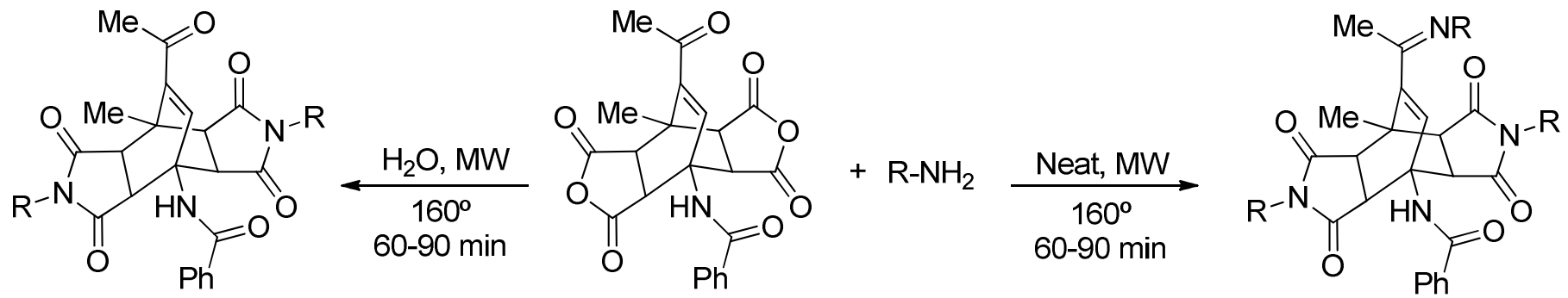

\section{Scheme 14}

MW-promoted imidation reactions have been extended to the synthesis of polyimides. Thus, polysuccinimide (PSI) has been prepared by MW-enhanced polycondensation of L-aspartic acid in the presence of a high boiling point solvent (Scheme 15). ${ }^{107,108}$

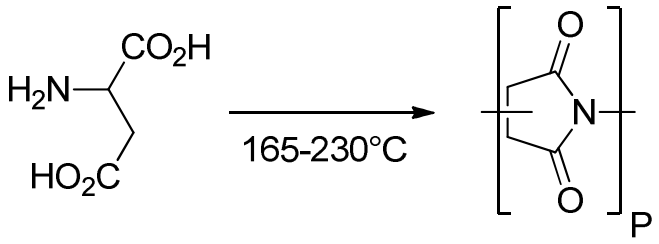

\section{Scheme 15}

In some cases, the use of catalysts has allowed improving the results of MW-promoted reactions in solution. Thus, the synthesis of $\mathrm{N}$-alkyl and $\mathrm{N}$-arylphthalimides has been achieved by eco-friendly $\mathrm{MW}$ irradiation methods, using Montmorillonite-KSF as a reusable clay catalyst in $\mathrm{AcOH}$ as solvent. ${ }^{9}$ Martínez-Palou et al. have explored the use of ionic liquids (ILs) as catalysts in these reactions. ${ }^{109}$ These authors synthesized bis-imides from dianhydrides or diamines with high melting points in $\mathrm{AcOH}$ as solvent. All ILs tested increased the reaction rates and yields. The best conversions were obtained with 1-butyl-4-methylpyridinium tetrafluoroborate ([BMPy]BF 4$)$ and 1-propyl-2,3-dimethylimidazolium iodide ([PMIM]I). An example is given in Scheme 16. 


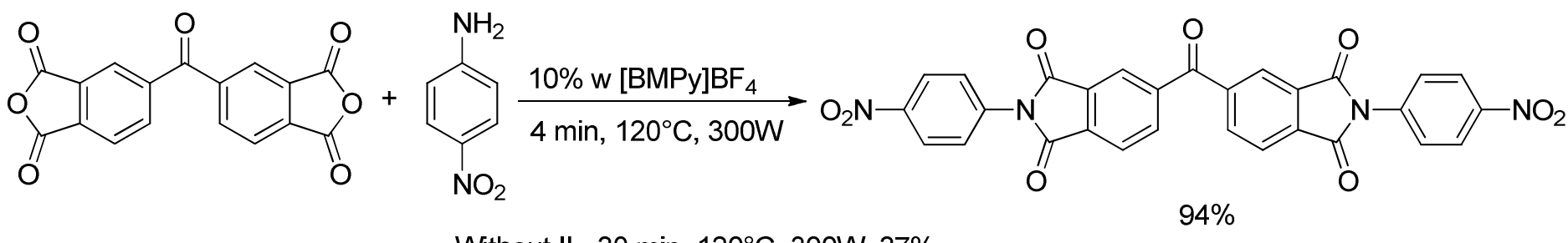

Without IL, $30 \mathrm{~min}, 120^{\circ} \mathrm{C}, 300 \mathrm{~W}, 37 \%$

\section{Scheme 16}

3.1.2 Solvent-free reactions. Solvent-free MW-mediated reactions are advantageous since they reduce the occurrence of hazardous explosions and eliminate the need to remove high boiling point aprotic solvents from the reaction mixture. In 1998, Sandhu et al. ${ }^{110}$ and Srivastava et al. ${ }^{111}$ described the one-pot synthesis of Nsubstituted maleimides and phthalimides by reaction of the corresponding anhydrides with aminoacids and alkyl amines using MW-promoted free-solvent reactions. Subsequently, Loupy and Gedye et al. ${ }^{112}$ re-evaluated some of those reactions using a monomode reactor with focused MW. That study demonstrated that solventfree $\mathrm{MW}$-assisted reactions need at least one liquid phase. This is possible if a liquid reactant or a solid with low melting point able to melt rapidly is used, giving a polar liquid which is more prone to $\mathrm{MW}$ absorption. ${ }^{113}$ If these conditions are not met, i.e. in reactions between two solids, the reaction does not proceed and requires the use of high boiling point solvents. These results were later corroborated by other researchers.

Seijas and Vázquez Tato have developed the direct MW-induced free-solvent synthesis of succinimides and homophthalimides from 1,4- and 1,5-dicarboxylic acids (Scheme 17). ${ }^{114}$ The reaction of malic acid under similar conditions rendered 3-hydroxy-2,5-pyrrolidinediones in moderate yields (59-72\%) together with lower amounts of the corresponding maleimides (14-19\%).<smiles>[R]C(CC(=O)O)C(=O)O</smiles>

$\mathrm{R}=\mathrm{H}, \mathrm{OH}$ $\mathrm{R}^{1}=\mathrm{H}, \mathrm{Cl}, \mathrm{OCH}_{3}$ $\mathrm{R}^{2}=\mathrm{H}, \mathrm{OCH}_{3}$ $\mathrm{R}^{3}=\mathrm{H}, \mathrm{Cl}$<smiles>[R]c1cc(C=NN)cc([R])c1[R]</smiles>

$n=0,1,2$
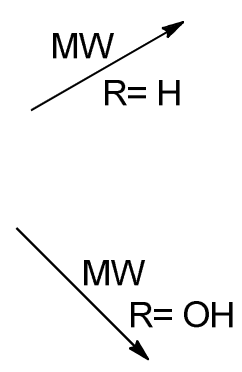<smiles>[R]c1cc(C=CC2C(=O)CC([R])C2=O)cc([R])c1[R]</smiles><smiles>[R]c1cc(C=CC2C(=O)CC([R])C2=O)cc([R])c1[R]</smiles>

$59-72 \%$<smiles>[R]c1cc(C=CC2C(=O)C=CC2=O)cc([R])c1[R]</smiles>

$14-19 \%$<smiles>[R]c1cc(-c2c[nH][nH]2)cc([R])c1[R]</smiles>

MW<smiles>[R]c1cc(C=CN2C(=O)Cc3ccccc3C2=O)cc([R])c1[R]</smiles>

\section{Scheme 17}


As indicated above (Section 2.1.3), Seijas et al. ${ }^{88}$ have described the synthesis of thalidomide by cyclization of the N-phthaloylglutamic acid with urea or thiourea. In the same work, thalidomide was also obtained in a one-pot MW-promoted procedure from equimolar amounts of glutamic acid, phthalic anhydride and thiourea, yielding $60 \%$ without obtaining significant amounts of pyroglutamic acid (Scheme 18). Thalidomide was obtained (44\%) by conventional heating techniques.

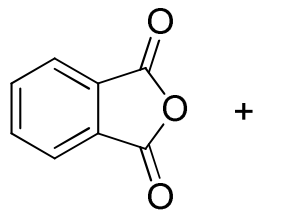<smiles>NC(CCC(=O)O)C(=O)O</smiles>
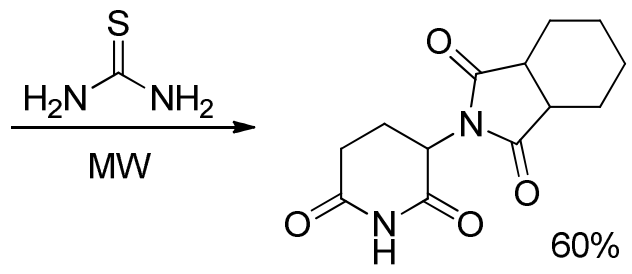

Scheme 18

Recently Benjamin and $\mathrm{Hijji}^{115}$ have reported the synthesis of thalidomide and thalidomide analogs (Scheme 19) under MW irradiation conditions through a one-pot reaction of glutamic acid with the corresponding anhydride and ammonium chloride, using DMAP as a basic catalyst $\left(150{ }^{\circ} \mathrm{C}, 10 \mathrm{~min}\right)$. Considerable quantities of the $\mathrm{N}$-unsubstituted cyclic imide are also produced during the reaction.

Although these are one-pot reactions, they require a multistep mechanism in which the glutamic acid has to form an amide-acid (amic acid) with the cyclic anhydride. If these open intermediates are not formed, then the reaction proceeds towards by-product formation with the $N$-unsubstituted cyclic imide as major product. Thus, the reaction of phthalic anhydride and glutamic acid with reagents that readily generate ammonia (such as ammonium acetate), is highly efficient at forming phthalimide (90\%) but not thalidomide (7\%). On the other hand, higher yields of thalidomide were obtained when DMAP/NH${ }_{4} \mathrm{Cl}$ were used.

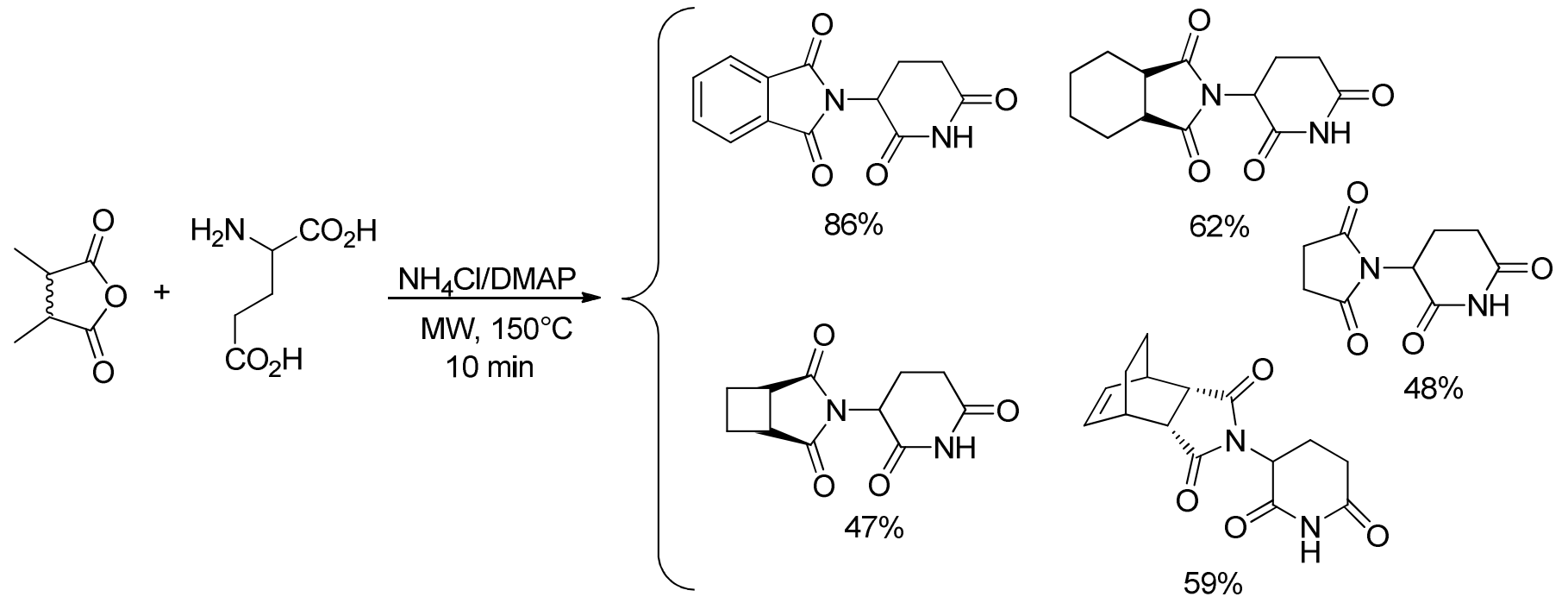

\section{Scheme 19}

Sondhi et al. have reported a solvent-free and high-yielding MW-promoted synthesis of bicyclo heterocyclic imides from heterocyclic diacids and heteroarylalkyl amines. ${ }^{116,117}$ Thus, a series of 2,3-pyrazine-, 4,5-imidazole-, 2,3- and 3,4-pyridinedicarboximides were obtained and evaluated for anticancer and antiinflammatory activities (Scheme 20). Seven-membered ring imides derived from diacids were also obtained (Scheme 21). 


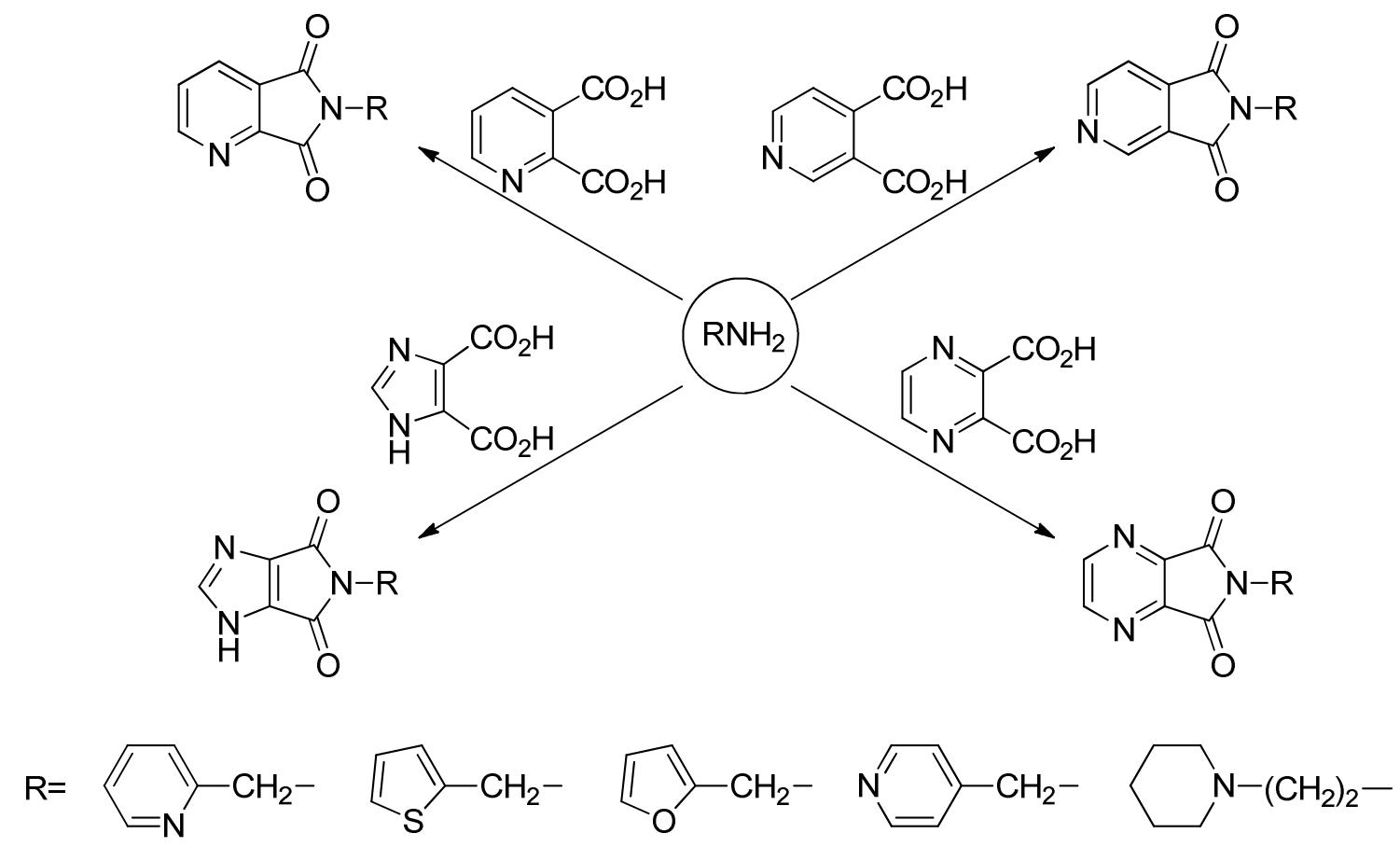

Scheme 20
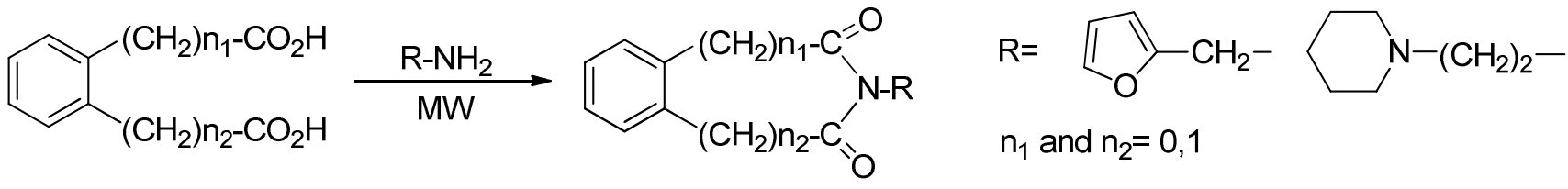

$\mathrm{n}_{1}$ and $\mathrm{n}_{2}=0,1$

\section{Scheme 21}

By simple irradiation of mixtures of anhydrides and amines, phthalimides and succinimides with different types of $\mathrm{N}$-substitution were obtained. ${ }^{8,118-121}$ A parallel synthesis of a representative 28-member library of phthalimides, has also been reported. ${ }^{122}$

In some cases, solvent-free $\mathrm{MW}$-assisted reactions require the use of catalysts or promoting agents. For example, Baldwin has described the first solventless preparation of imides from sterically hindered acids (such as Kemp's triacid) in the presence of imidazole in unsealed reaction vessels (Scheme 22 ). ${ }^{123}$ The activity of the imidazole as promoting agent was attributed to the ability to form polar carboxylic acid salts for efficient MW energy absorption, and to the formation of anhydride species, generally considered fast reacting intermediates in condensation reactions.
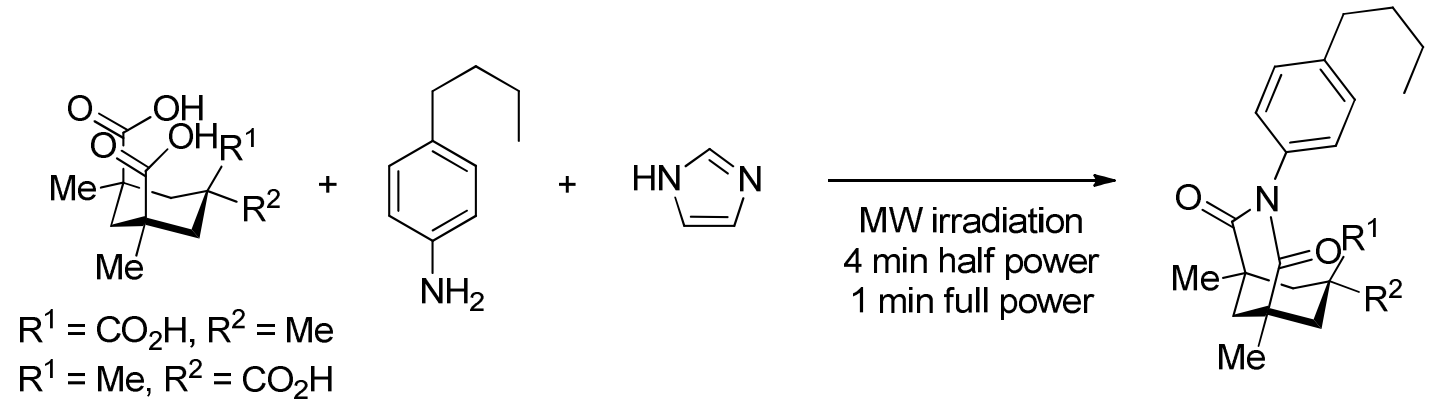

\section{Scheme 22}


Inorganic solid supports are useful media for the rapid and efficient synthesis of different imides under "dry" conditions. Inorganic oxides such as silica and various types of alumina have been used for the synthesis of different types of imides. ${ }^{124-126}$ Montmorillonite clays were also used as support and catalyst for a variety of organic reactions, offering several advantages over other supports. For example, the strong acidity, noncorrosive properties, cheapness, the requirement of mild reaction conditions, high yields and selectivity, and the easy working up. Mortoni et al. have synthesized a library of $\mathrm{N}$-substituted quinoline-3,4-dicarboximides with different moieties from the reaction of the corresponding anhydride and several primary amines (Scheme 23). They tested different supports, such as silica, neutral, acid and basic alumina, and Montmorillonite K$10 .^{127}$ The authors found that wet Montmorillonite (commercial Montmorillonite) proved to be the best medium for the condensation, leading to a complete conversion of reactants. This result was not obtained when vacuum-dried Montmorillonite was used. This effect was attributed to the presence of an unquantified amount of water, in the commercial product, that interacts with MW and increases the medium capacity to absorb the MW energy.
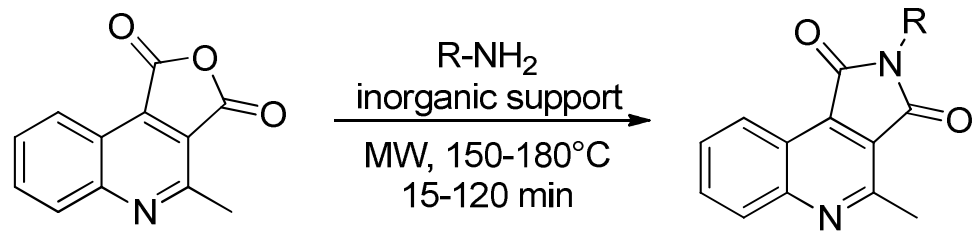

$60-95 \%$ (22 examples)

\section{Scheme 23}

Habibi et al. have used Montmorillonite KSF and K-10 as efficient catalysts for the solventless synthesis of bis-maleimides and bis-phthalimides from the appropriate anhydride and aliphatic and aromatic diamines using MW irradiation. ${ }^{128}$ Good yields, short reaction times and the easy recovery and reuse of the natural clay are the advantages of this method.

Chandrasekhar has described the first Lewis acid-catalyzed and solvent-free procedure for the preparation of a variety of imides from the corresponding anhydrides and different amines employing silica-gel as support and $\mathrm{TaCl}_{5}-\mathrm{SiO}_{2}$ as catalyst under MW irradiation (Scheme 24). ${ }^{129}$ The good results achieved are due to the high oxophilicity of $\mathrm{TaCl}_{5}$, the affinity of activated silica gel as water scavenger and the rapid heating capacity of the MW oven.

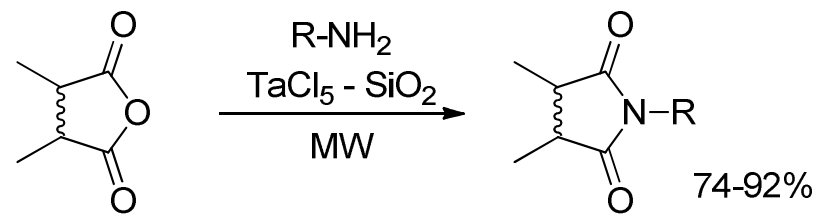

\section{Scheme 24}

Chandrasekhar et al. have modified the previous methodology by transforming it into a synthesis on a polymeric support (SPOS). ${ }^{130}$ The authors employed, for the first time, two insoluble supports, namely Merrifield's resin and silica gel. The polymeric resin was esterified with an amino acid such as $\gamma$-aminobutyric acid or alanine. The subsequent MW-promoted reaction with an anhydride (phthalic, succinic or maleic) in the presence of the catalyst led to the generation of the polymer-bound imide which is cleaved by treatment with trifluoroacetic acid to furnish $\mathrm{N}$-carboxyalkyl imides (Scheme 25). 


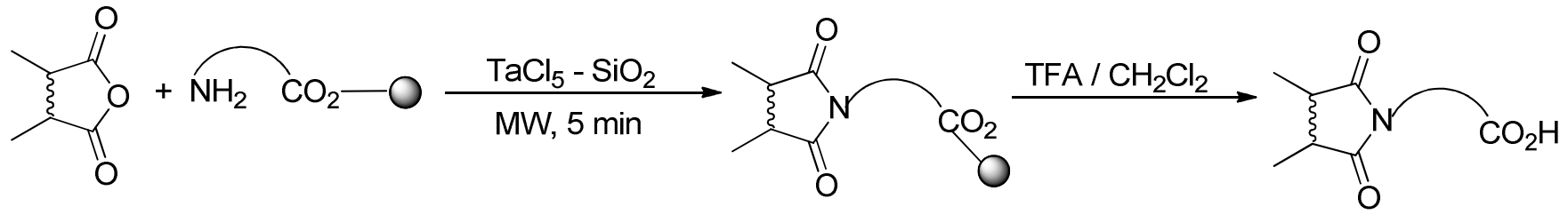

\section{Scheme 25}

\subsection{Amic acid cyclizations}

Cyclization of amic acids in the presence of acidic reagents is a typical method for obtaining imides. However, literature data describing the use of MW for cyclization are scarce. Perillo et al. ${ }^{81}$ have developed methods for the synthesis of $\mathrm{N}$-substituted 2,3-pyridinedicarboximides (quinolinimides) by aminolysis of the anhydride. The authors observed that when the amine could be used directly as free base, it was convenient to isolate the amic acid intermediates and then proceed to their cyclization (Scheme 26).

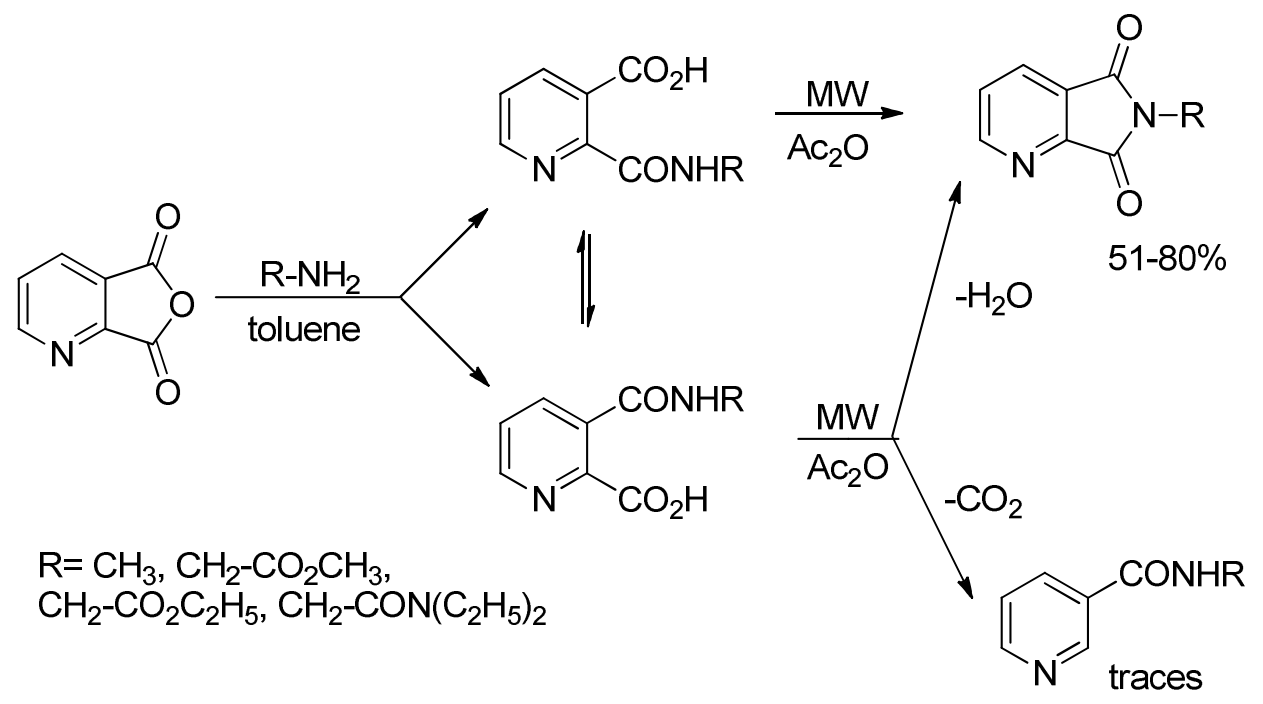

\section{Scheme 26}

Thus, in the first step the amic acids from quinolinic anhydride were generated employing a low polarity solvent. Subsequently, the MW-promoted cyclization in acetic anhydride led, in short times, to imides as the major products, with good yields and high purity. Amounts of nicotinamide as secondary product did not exceed $5 \%$ and in some cases only traces of such by-product were obtained.

Cyclization of amic acids has also been applied to the synthesis of polyimides. Thus, Lewis et al. have described the MW-promoted imidation of a polyamic acid (prepared from 3,3',4,4'-benzophenonetetracarboxylic acid dianhydride (BTDA) and diaminophenylsulfone (DDS)) in $N$-methylpyrrolidinone (NMP) (Scheme 27). ${ }^{131}$ 
<smiles>O=C(c1ccc2c(c1)C(=O)OC2=O)c1ccc2c(c1)C(=O)OC2=O</smiles><smiles>Nc1cccc(OS(=O)(=O)c2cccc(N)c2)c1</smiles><smiles>CCOS(=O)(=O)c1cccc(NC(=O)c2cc(C(=O)c3ccc(C(=O)Nc4cccc(S(C)(=O)=O)c4)c(C(=O)Nc4cccc(OS(C)(=O)=O)c4)c3)ccc2C(=O)O)c1</smiles>

Scheme 27

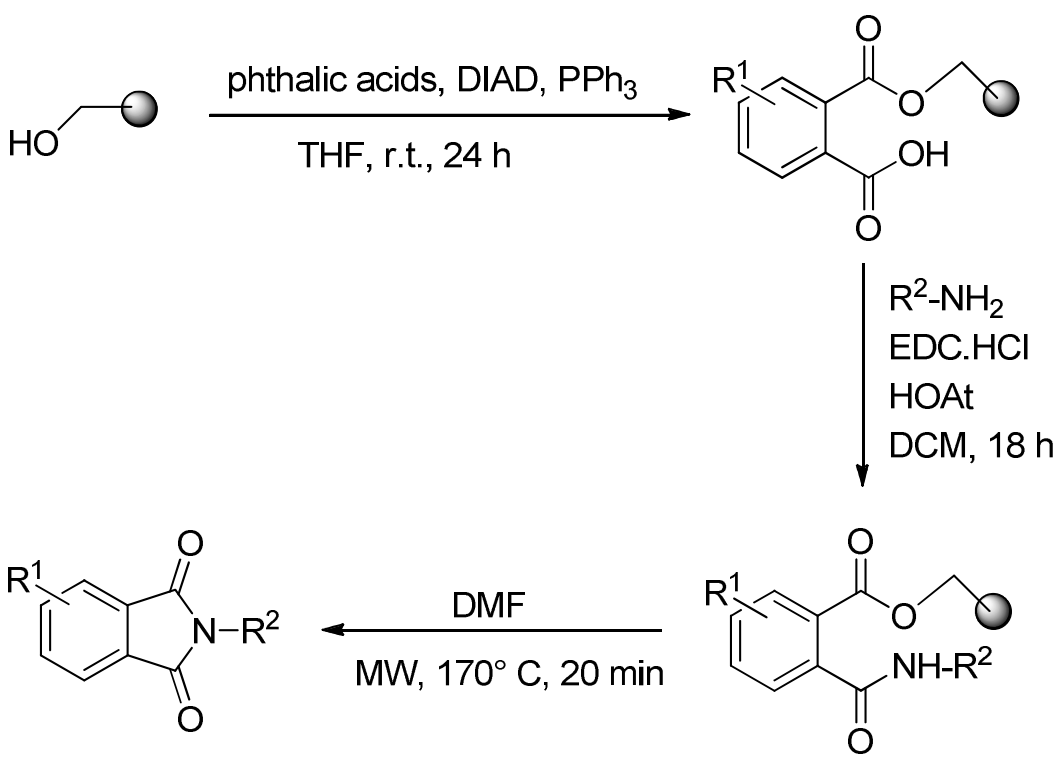

\section{Scheme 28}

The use of MW to promote cyclization of amic acids was extended to other techniques, such as solid phase synthesis. Chassaing et al. have developed a traceless solid-phase synthesis of $\mathrm{N}$-substituted phthalimide libraries. ${ }^{132}$ The synthetic route involves the use of the Wang resin loaded with phthalic acid employing the Mitsunobu protocol. Subsequent reaction with alkyl or aralkyl amines under standard amide coupling conditions led to the generation of resin-bound $\mathrm{N}$-alkyl or benzylphthalamic acids. Finally, the isolated resin 
suspended in DMF was irradiated in a single monomode $\mathrm{MW}$ reactor ( $170{ }^{\circ} \mathrm{C}$ for $20 \mathrm{~min}$ ) affording $\mathrm{N}$-substituted phthalimides in good yields and excellent purity (Scheme 28). The authors emphasized the fact that the reaction proceeds well with fluoro-substituted phthalimides. Previous attempts to synthesize these compounds in solution were unsuccessful due to aromatic nucleophilic substitution of the fluorine by the amines as a side reaction.

\subsection{N-Alkylation of imides with halogenated compounds}

The method involves the alkylation of an unsubstituted imide, easily obtained from the dicarboxylic acid or its corresponding anhydride (see 2.1 and 2.2). The reaction proceeds in basic medium to generate the strongly nucleophilic imide anion. The most common procedure makes use of alkyl halides, either in a reaction with the preformed imide salt or generating the stabilized imide anion in situ (Scheme 29). Taking into account that the reaction takes place through an $\mathrm{S}_{\mathrm{N}} 2$ mechanism, its application is limited by the nature of the alkylating agent. Therefore, it is not useful to obtain $\mathrm{N}$-aryl or N-tert-alkyl derivatives.

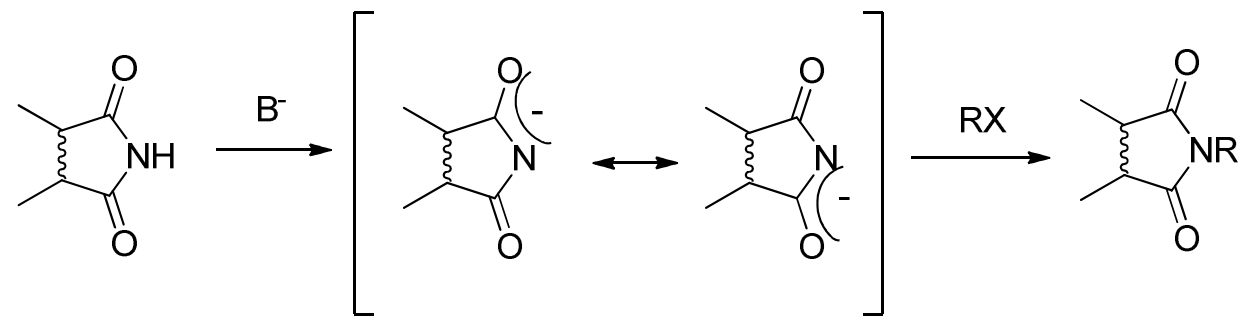

\section{Scheme 29}

This methodology is perfectly compatible with the use of $\mathrm{MW}$, and is versatile, since allows the reactions to be conducted with or without solvent; the use of PTC, supported reagents, different type of bases, the salt of the imide or its in situ generation.

3.3.1 Reactions in solution. N-Alkylation of quinolinimides has easily been achieved by MW irradiation of a mixture of quinolinimide, triethylamine and the corresponding alkyl halide in dry DMF. ${ }^{81}$ The method represents a typical example of the MORE chemistry developed by Bose ${ }^{95}$ and gives good results for the substitution of the quinolinimide hydrogen by alkyl (even secondary), aralkyl and functionalized alkyl groups. Blanco et al. have reported an efficient and simple method for the $\mathrm{N}$-alkylation of aromatic cyclic imides employing $\mathrm{Cs}_{2} \mathrm{CO}_{3}$ as base in anhydrous DMF at low temperatures $\left(20-70{ }^{\circ} \mathrm{C}\right) .{ }^{133}$ The $\mathrm{MW}$ irradiation presented noteworthy advantages over the conventional heating. Thus, phthalimide, naphthalimide and heteroaromatic imides were synthesized. Reactions proceeded efficiently with various functionalized primary alkyl halides, including 3-bromopropionic acid derivatives. The method is especially suitable for pyridine and pyrazinedicarboximides having a labile base nucleus due to the presence of the pyridine nitrogen. A similar technology using other basic agents $\left(\mathrm{KOH}, \mathrm{K}_{2} \mathrm{CO}_{3}\right)$ allowed the synthesis of phthalimides with different types of N-substituents. ${ }^{13,80,134-136}$

3.3.2 Solvent-free reactions. In general, free-solvent reactions require the use of PTC and/or reagents adsorbed on inorganic supports. In 1996, Bogdal described, for the first time, the N-alkylation of an imide (phthalimide) in dry media under PTC. ${ }^{137}$ The synthesis was carried out by simple mixing of phthalimide with $25 \%$ excess of an alkyl halide and a catalytic amount of TBAB. The mixtures were adsorbed on $\mathrm{K}_{2} \mathrm{CO}_{3}$ and irradiated in an open Erlenmeyer flask in a domestic microwave oven. 
Asadolah et al. have reported the synthesis of $\mathrm{N}$-alkylphthalimides and succinimides through alkylation of potassium phthalimide and succinimide in dry media catalyzed by PTC under MW irradiation. ${ }^{138}$ The reactions were carried out by MW irradiation of a mixture of potassium phthalimide or succinimide, an excess of alkyl halide and a catalytic amount of TBAB adsorbed on silica gel.

\section{Acknowledgements}

This work was financially supported by the Universidad de Buenos Aires.

\section{References}

1. Haergreeves, M.; Prtichard, J.; Dav, H. Chem. Rev. 1970, 70, 439-469. https://doi.org/10.1021/cr60266a001

2. Cechinel Filho, V.; Campos, F.; Corrêa, R.; Yunes, R.; Nunes, R. Quim. Nova 2003, 26, 230-241.

3. Sharma, U.; Kumar, P.; Kumar, N.; Singh, B. Mini-Rev. Med. Chem. 2010, 10, 678-704.

4. Kushwaha, N.; Kaushik, D. J. of Appl. Pharm. Sci. 2016, 6, 159-171. https://doi.org/10.7324/JAPS.2016.60330.

5. Marulasiddaiah, R.; Kalkhambkar, R.; Kulkarni, M. Open J. Med. Chem. 2012, 2, 89-97. https://doi.org/10.4236/ojmc.2012.23011.

6. Légora Machado, A.; Moreira Lima, L.; Araújo-Jr, J.; Fraga, C.; Gonçalves Koats, V.; Barreiro, E. Bioorg. Med. Chem. Lett. 2005, 15, 1169-1172. https://doi.org/10.1016/i.bmcl.2004.12.012.

7. Chapman, J.; De Lucy, P.; Wong, O.; Hall, I. Lipids 1990, 25, 391-397. https://doi.org/10.1007/BF02537982.

8. Fhid, O.; Zeglam, T.; Saad, S.; Elmoug, T.; Eswayah ,A.; Zitouni, M.; Sdera, W.; Edeep, A.; Ebzabez, A. Der Pharma Chemica 2014, 6, 234-238.

http://derpharmachemica.com/archive.html

9. Gajare, S.; Mahajan, S. Int. J. Pharm. Phytopharmacol. Res. 2012, 1, 357-362.

10. Knölker, H-J.; Reddy, K. Chem. Rev. 2002, 102, 4303-4427. https://doi.org/10.1021/cr020059j.

11. Bhat, M.; Al-Omar, M.; Siddiqui, N. Der Pharma Chemica 2010, 2, 1-10. http://derpharmachemica.com/archive.html

12. Langade, M. Der Pharma Chemica 2011, 3, 283-286.

http://derpharmachemica.com/archive.html

13. Pawar, N.; Patil, J.; Suryawanshi, K.; Chaudhary, S.; Patil, P. Der Pharma Chemica 2012, 4, 15-22. http://derpharmachemica.com/archive.html

14. Wuts, P.; Greene, T. Greene's Protective Groups in Organic Synthesis, 4th Edn; Wiley: New York, 2007.

15. Huang, J.; Wang, X.; Zhan, C.; Zhao, Y.; Sun, Y.; Pei, Q.; Liu, Y.; Yao, J. Polym. Chem. 2013, 4, $2174-2182$. http://dx.doi.org/10.1039/C3PY21134G

16. Mitrović, A.; Todorović, N.; Žekić, A.; Stanković, D.; Milić, D.; Maslak, V. Eur. J. Org. Chem. 2013, 11, 21882193. 
17. Recupero, F.; Punta, C. Chem. Rev. 2007, 107, 3800-3842. https://doi.org/10.1021/cr040170k

18. Okamoto, H.; Konishi, H.; Satake, K. Chem. Commun. 2012, 48, 2346-2348. https://doi.org/10.1039/C2CC17502A

19. Weinberger, M.; Berndt, F.; Mahrwald, R.; Ernsting, N.; Wagenknecht, H. J. Org. Chem. 2013, 78, 25892599.

https://doi.org/10.1021/jo302768f

20. Vakte, P.; Bhagwat, M.; Bagul, S. Inventi Rapid: Med. Chem. 2016, 2, 1-7. http://inventi.in/journal/article/rapid/5/19337/med-chem/pi\#

21. Kafi, K.; Betting, D. ; Yamada, R.; Bacica, M.; Steward, K.; Timmerman, J. Mol. Immunol. 2009, 46, 448456.

https://doi.org/10.1016/i.molimm.2008.10.020

22. Karim, A.; Johansson, C.; Weltman, J. Nucleic Acids Res. 1995, 23, 2037-2040. https://doi.org/10.1093/nar/23.11.2037

23. Wu, M.-D.; Cheng, M.; Wang, B.-C.; Yech, Y.-J.; Lai, J.-T.; Kuo, Y.-H.; Yuan, G.-F.; Chen, I.-S. J. Nat. Prod. 2008, 71, 1258-1261.

https://doi.org/10.1021/np070634k

24. Wattanadilok, R.; Sawangwong, P.; Rodrigues, C.; Cidade, H.; Pinto, M.; Pinto, E.; Silva, A.; Kijjoa, A. Mar. Drugs 2007, 5, 40-51.

https://doi.org/10.3390/md502040

25. Matuszak, N.; Muccioli, G.; Labar, G.; Lambert, D. J. Med. Chem. 2009, 52, 7410-7420. https://doi.org/10.1021/jm900461w

26. Baldwin, S.; Greenspan, P.; Alaimo, C.; McPhail, A. Tetrahedron Lett. 1991, 32, 5877-5880. https://doi.org/10.1016/S0040-4039(00)79415-9

27. Philp, D.; Robertson, A. J. Chem. Soc., Chem. Commun. 1998, 879-880. https://doi.org/10.1039/A800559A

28. Bravo, P.; Pozo Carero, M.; Román Galán, E.; Serano Blázquez, J. Heterocycles 2000, 53, 81-92. https://doi.org/10.3987/COM-99-8723

29. Nair, D.; Podgórski, M.; Chatani, S.; Gong, T.; Xi, W.; Fenoli, C.; Bowman, C. Chem. Mater. 2014, 26, 724744.

https://doi.org/10.1021/cm402180t

30. Sanyal, A. Macromol. Chem. Phys. 2010, 211, 1417-1425.

https://doi.org/10.1002/macp.201000108

31. Grigg, R.; Surendrakumar, S.; Thiampatanagul, S.; Vipond, D. J. Chem. Soc., Perkin Trans. 1 1988, 26932701. https://doi.org/10.1039/P19880002693

32. Blanáriková, I.; Dugovič, B.; Fišera, L.; Hametner, C. Arkivoc 2001, (ii), 109-121. http://dx.doi.org/10.3998/ark.5550190.0002.218

33. Philp, D.; Booth, C. A. Tetrahedron Lett. 1998, 39, 6987-6990.

PII: S0040-4039(98)01483-X

34. Dolci, E.; Froidevaux, V.; Joly-Duhamel, C.; Auvergne, R.; Boutevin, B.; Caillol, S. Polym. Rev. 2016, 56, 512-556.

http://www.tandfonline.com/action/showCitFormats?doi=10.1080/15583724.2015.1116094 
35. Łuszczki, J.; Marzęda, E.; Kondrat-Wróbel, M.; Wróbel, J.; Kocharov, S.; Florek-Łuszczki, M. J. Pre-Clinical and Clinical Research 2014, 8, 34-37.

http://www.jpccr.eu/Effect-of-N-p-ethoxycarbonylphenylmethyl-p-isopropoxyphenylsuccinimide-onthe-anticonvulsant,71462,0,2.html

36. Kamiński, K.; Obniska, J.; Chlebek, I.; Liana, P.; Pękala, E. Eur. J. Med. Chem.2013, 66, 12-21. https://doi.org/10.1016/i.ejmech.2013.05.011

37. Patil, M.; Rajput, S. Int. J. Pharm. Pharm. Sci. 2014, 6, 8-14.

38. Dhivare, R.; Rajput, S. World J. Pharm. Res. 2015, 4, 1650-1658.

https://www.researchgate.net/publication/289530880

39. Sortino, M.; Postigo, A.; Zacchino, S. Molecules 2013, 18, 5669-5683.

https://doi.org/10.3390/molecules18055669

40. Dhivare, R.; Rajput, S. Int. J. Chem. Pharm. Sci. 2015, 3, 1877-1880.

41. Peixoto, R.; Guilhon, G.; Zoghbi, M.; Araújo, I.; Uetanabaro A.; Santos, L.; Brasil, D. Molecules 2013, 18, 3195-3205.

https://doi.org/10.3390/molecules18033195

42. Shah, J.; Swartz, G.; Papathanassiu, A.; Treston, A.; Fogler, W.; Madsen, J.; Green, S. J. Med. Chem. 1999, 42, 3014-3017.

https://doi.org/10.1021/jm990083y

43. Teo, S. The AAPS Journal 2005, 7, Article 3 (http://www.aapsj.org). https://doi.org/10.1208/aapsj070103

44. Dalgleish, A.; Galustian, C. Future Oncol. 2010, 6, 1479-1484. https://doi.org/10.2217/fon.10.105

45. Shortt, J.; Hsu, A.; Johnstone, R. Oncogene 2013, 32, 4191-4202. https://doi.org/10.1038/onc.2012.599

46. Moreira, A.; Corral, L.; Ye, W.; Johnson, B.; Stirling, D.; Müller, G.; Freedman, V.; Kaplan, G. AIDS Res. Human Retroviruses 1997, 13,857-863.

https://doi.org/10.1089/aid.1997.13.857

47. Banerjee, S.; Veale, E.; Phelan, C.; Murphy, S.; Tocci, G.; Gillespie, L.; Frimannsson, D.; Kelly, J.; Gunnlaugsson, T. Chem. Soc. Rev. 2013, 42, 1601-1618. https://doi.org/10.1039/C2CS35467E

48. Tandon, R.; Luxami, V.; Kaur, H.; Tandon, N.; Paul, K. Chem. Rec. 2017, 17, 1-39. https://doi.org/10.1002/tcr.201600134

49. Ge, C.; Chang, L.; Zhao, Y.; Chang, C.; Xu, X.; He, H.; Wang, Y.; Dai, F.; Xie, S.; Wang, C. Molecules 2017, 22, 342.

https://doi.org/10.3390/molecules22020342

50. Śladowska, H.; Sabiniarz, A.; Szkatufa, D.; Filipek, B.; Sapa, J. Acta Poloniae Pharm.-Drug Res., 2006, 63, 245-254, and references cited therein.

51. Śladowska, H.; Filipek, B.; Szkatuła, D.; Sapa, J.; Bednarski, M.; Ciołkowska, M. I/ Farmaco 2005, 60, 5359.

https://doi.org/10.1016/i.farmac.2004.08.011

52. Krzyżak, E.; Szkatuła, D.; Szczęśniak-Sięga, B.; Malinka, W. J. Therm. Anal. Calorim. 2015, 120, 847-853. https://doi.org/10.1007/s10973-014-3802-7

53. Muszalska, I.; Jankowska, A. Anal. Lett. 2010, 43, 1003-1018.

https://doi.org/10.1080/00032710903491120 
54. Abdel-Aziz, A. Eur. J. Med. Chem. 2007, 42, 614-626.

https://doi.org/10.1016/i.ejmech.2006.12.003

55. Gawande, M.; Shelke, S.; Zboril, R.; Varma, R. Acc. Chem. Res. 2014, 47, 1338-1348. https://doi.org/10.1021/ar400309b

56. Bilecka, I.; Niederberger, M. Nanoscale, 2010, 2, 1358-1374. https://doi.org/10.1039/B9NR00377K

57. Kappe, C. O.; Stadler, A., Microwaves in Organic and Medicinal Chemistry, Wiley-VCH; Weiheim, 2012.

58. Lidström, P. Microwave-Assisted Organic Synthesis; Tierney, J. P.; Eds.; Blackwell Scientific, 2005.

59. Driowya, M.; Saber, A.; Marzag, H.; Demange, L.; Bougrin, K.; Benhida, R. Molecules 2016, $21,1032$. https://doi.org/10.3390/molecules21081032

60. De la Hoz, A.; Loupy, A. Microwaves in Organic Synthesis, 3rd Edn.; Springer: New York, USA, 2012.

61. Garella, D.; Borretto, E.; Di Stilo, A.; Martina, K.; Cravotto, G.; Cintas, P. Med. Chem. Commun. 2013, 4, 1323-1343.

https://doi.org/10.1039/C3MD00152K

62. Jacob, J. Int. J. Chem. 2012, 4, 29-43. https://doi.org/10.5539/ijc.v4n6p29

63. Gedye, R.; Smith, F.; Westaway, K.; Ali, H.; Baldisera, L.; Laberge, L.; Rousell, J. Tetrahedron Lett. 1986, 27, 279-282.

https://doi.org/10.1016/S0040-4039(00)83996-9

64. Giguère, R.; Bray, T.; Duncan, S.; Majetich, G. Tetrahedron Lett. 1986, 27, 4945-4948. https://doi.org/10.1016/S0040-4039(00)85103-5

65. Anastas, P.; Warner, J. Green Chemistry: Theory and Practice; Oxford University Press, Oxford, 2000.

66. Polshettiwar, V.; Varma, R. Acc. Chem. Res. 2008, 41, 629-639.

https://doi.org/10.1021/ar700238s

67. Bougrin, K.; Loupy, A.; Soufiaoui, M. J. Photochem. Photobiol. C: Photochem. Rev. 2005, 6, 139-167. https://doi.org/10.1016/i.jphotochemrev.2005.07.001

68. Gawande, M.; Bonifacio, V.; Luque, R.; Branco, P.; Varma, R. ChemSusChem 2014, 7, 24-44. https://doi.org/10.1002/cssc.201300485

69. Polshettiwar, V.; Varma, R. Chem. Soc. Rev. 2008, 37, 1546-1557. https://doi.org/10.1039/B716534J

70. Dallinger, D.; Kappe, C. Chem. Rev. 2007, 107, 2563-2591.

https://doi.org/10.1021/cr0509410

71. Gawande, M.; Bonifacio, V.; Luque, R.; Branco, P.; Varma, R. Chem. Soc. Rev. 2012, 42, 5522-5551. https://doi.org/10.1039/C3CS60025D

72. Gupta, M; Paul, S.; Gupta, R. Acta Chim. Slov. 2009, 56, 749-764.

73. Cravotto, G.; W. Bonrath, W.; Tagliapietra, S.; Speranza, C.; Calcio Gaudinoa, E.; Barge, A. Chem. Eng. Process. 2010, 49, 930-935. https://doi.org/10.1016/i.cep.2010.07.004

74. Rodríguez, A.; Juan, A.; Gómez, M.; Moreno, A.; de la Hoz, A. Synthesis 2012, 44, 2527-2530. https://doi.org/10.1055/s-0031-1290944

75. Pavlovskaya, T.; Red'kin, R.; Yaremenko, F.; Shishkina, S.; Shishkin, O.; Musatov, V.; Lipson, V. Chem. Heterocycl. Comp. 2013, 49, 811-826. https://doi.org/10.1007/s10593-013-1322-1

76. Cravotto, G.; Cintas, P. Chem. Eur. J. 2007, 13, 1902-1909. 
https://doi.org/10.1002/chem.200601845

77. Leonelli, C.; Mason, T. Chem. Eng. Process. 2010, 49, 885-900. https://doi.org/10.1016/i.cep.2010.05.006

78. Erdélyi, M. Top. Heterocycl. Chem. 2006, 1, 79-128. https://doi.org/10.1007/7081 001

79. Rajak, H.; Mishra, P. J. Sci. Ind. Res. 2004,63, 641-654.

80. Pawar, N.; Garud, S.; Patil, V. Der Pharmacia Lettre 2012, 4, 1129-1136. http://scholarsresearchlibrary.com/archive.html

81. Blanco, M.; Levin, G.; Schapira, C.; Perillo, I. Heterocycles 2002, 57, 1881-1890. https://doi.org/10.3987/COM-02-9524

82. Hijji, Y.; Benjamin, E. Heterocycles 2006, 68, 2259-2267. https://doi.org/10.3987/COM-06-10841

83. Peng, Y.; Song, G.; Qian, X. Synthetic Commun. 2001, 31, 1927-1931. http://dx.doi.org/10.1081/SCC-100104345

84. Kacprzak, K. Synthetic Commun. 2003, 33, 1499-1507. http://doi.org/10.1081/SCC-120018768

85. Taherpour, A.; Abramian, A.; Kardanyazd, H. Asian J. Chem. 2006, 18, 2401-2403.

86. Banerji, A.; Kanti Biswas, P.; Sengupta, P.; Dasgupta, S.; Gupta, M. Indian J. Chem. 2004, 43B, 882-884.

87. Cai, Y-H. Asian J. Chem. 2012, 24, 481-484.

88. Seijas, J.; Vázquez-Tato, M.; González-Bande, G.; Martínez, M.; Pacios-López, B. Synthesis 2001, 9991000. https://doi.org/10.1055/s-2001-14573

89. Taherpour, A.; Kheradmand, K. Asian J. Chem. 2008, 20, 3341-3344.

90. Nikpour, F.; Kazemi, S.; Sheikh, D. Heterocycles 2006, 68, 1559-1564. https://doi.org/10.3987/COM-06-10762

91. Benjamin, E.; Hijji, Y. Molecules 2008, 13, 157-169. http://dx.doi.org/10.3390/molecules13010157

92. Taherpour, A.; Mansuri, H. Turk. J. Chem. 2005, 29, 317-320.

93. Taherpour, A.; Abramian, A.; Kardanyazd, H. Chinese J. Org. Chem. 2007, 27, 123-125.

94. Wu, X.; Mahalingam, A.; Wan, Y.; Alterman, M. Tetrahedron Lett. 2004, 45, 4635-4638. https://doi.org/10.1016/i.tetlet.2004.04.110

95. Bose, A.; Manhas, M.; Ghosh, M.; Raju, V.; Tabei, K.; Urbancyk-Lipkowska, Z. Heterocycles 1990, 30, 741744.

https://doi.org/10.3987/COM-89-S42

96. Westaway, K.; Gedye, R. J. Microwave Power Electromagnetic Energy 1995, 31, 219-230. http://dx.doi.org/10.1080/08327823.1995.11688280

97. Bari, S.; Bose, A.; Chaudhary, A.; Manhas, M.; Raju, V.; Robb, E. J. Chem. Ed. 1992, 69, 938-939. https://doi.org/10.1021/ed069p938

98. Bose, A.; Jayaraman, M.; Okawa, A.; Bari, S.; Robb, E.; Manhas, M. Tetrahedron Lett. 1996, 37, 69896992. https://doi.org/10.1016/0040-4039(96)01571-7

99. Cros, E.; Planas, M.; Bardají, E. Synthesis 2001, 1313-1320. https://doi.org/10.1055/s-2001-15215

100. Upadhyaya, S.; Pingalia, S.; Jursica, B. Tetrahedron Lett. 2010, 51, 2215-2217. 
https://doi.org/10.1016/j.tetlet.2010.02.092

101. Mogilaiah, K.; Sakram, B. Indian J. Chem. 2007, 46B, 207-209.

http://nopr.niscair.res.in/handle/123456789/469

102. Bose, A.; Manhas, M.; Ghosh, M.; Shah, M.; Raju, V.; Bari, S.; Newaz, S.; Banik, B.; Chaudhary, A.;

Barakat, K. J. Org. Chem. 1991, 56, 6968-6970.

https://doi.org/10.1021/j000025a004

103. Chorell, E.; Chorell, E. Eur. J. Org. Chem. 2013, 33, 7512-7516.

https://doi.org/10.1002/ejoc.201300952

104. Saedi, H. J. Adv. Chem. 2014, 10, 2276-2282.

https://cirworld.com/index.php/iac/article/view/4268

105. Ondruš, V.; Fišera, L.; Bradac, V. Arkivoc 2001, (v), 60-67.

http://www.arkat-usa.org/get-file/18931/

106. Hren, J.; Kranjc, K.; Polanc, S.; Kočevar, M. Synthesis 2008, 452-458.

https://doi.org/10.1055/s-2008-1032038

107. Piątkowski, M.; Bogdał. D.; Raclavský, K. Int. J. Polym. Anal. Charact. 2015, 20, 714-723.

http://dx.doi.org/10.1080/1023666X.2016.1081134

108. Piątkowski, M.; Bogdał. D.; Ondruschka, B. Polimery 2009, 54, 573-576.

109. Guzmán-Lucero, D.; Likhanova, N.; Höpfl, H.; Guzmán, J.; Likhatchev, D.; Martínez-Palou, R. Arkivoc 2006, $(x), 7-20$.

http://dx.doi.org/10.3998/ark.5550190.0007.a02

110. Borah, H.; Boruah, R.; Sandhu, J. S. J. Chem Res. (S) 1998, 272-273.

https://doi.org/10.1039/A707961C

111. Antunes, R.; Batista, H.; Srivastava, R.; Thomas, G.; Araujo, C. Bioorg. Med. Chem. Lett. 1998, 8, 30713076.

https://doi.org/10.1016/S0960-894X(98)00558-7

112. Vidal, T.; Petit, A.; Loupy, A.; Gedye, N. Tetrahedron 2000, 56, 5473-5478.

http://dx.doi.org/10.1016/S0040-4020(00)00445-2

113. Santos, J.; Lima, L.; Chung, M. Rev. Ciênc. Farm. Básica Apl. 2006, 27, 163-167. ISSN 1808-4532.

114. Seijas, J.; Vázquez-Tato, M.; Montserrat Martínez, M.; Núñez-Corredoira, G. J. Chem Res. (S) 1999, 420421.

http://dx.doi.org/10.1039/A901520E

115. Benjamin, E.; Hijji, Y. J. of Chemistry 2017, Article ID: 6436185.

https://doi.org/10.1155/2017/6436185

116. Sondhi, S.; Rani, R.; Roy, P.; Agrawal, S.; Saxena, A. Bioorg. Med. Chem. Lett. 2009, 19, 1534-1538.

https://doi.org/10.1016/i.bmcl.2008.07.048

117. Sondhi, S.; Rani, R. Lett. Org. Chem. 2008, 5, 51-54.

https://doi.org/10.2174/157017808783330180

118. Li, H-Z.; Zhang, J-S.; Zhou, Y-M.; Li, T-S. Synth. Commun. 2002, 36, 927-929.

http://dx.doi.org/10.1081/SCC-120002706

119. Demnitz, J.; Monteiro, B.; Ramos, M.; Srivastava, R. Heterocycl. Commun. 1997, 3, 115-122. https://doi.org/10.1515/HC.1997.3.2.115

120. Awad, B.; Abdallah, S.; Hefny, H.; Abdou, M.; Abd-Elmonem, F.; Abd-Elmonem, N. Life Sci. J. 2012, 9, 567577.

http://dx.doi.org/10.7537/marslsj090412.86 
121. Abdallah, S.; Hefny, H. Turk. J. Chem. 2011, 35, 463-474. https://doi.org/10.3906/kim-1007-807

122. Barchín, B.; Cuadro, A.; Alvarez-Builla, J. Synlett 2002, 343-345. https://doi.org/10.1055/s-2002-19765

123. Baldwin, B.; Hirose, T.; Wang, Z-H. Chem. Commun. 1996, 2669-2670. https://doi.org/10.1039/CC9960002669

124. Mogilaiah, K.; Prashanthi, M.; Reddy, G. Indian J. Heterocycl. Chem. 2003, 12, 389-390. ISSN 0971-1627.

125. Gadre, J.; Vardhan, D.; Nair, L.; Mulay, M.; Vaze, C. Res. J. Chem. Environ. 2004, 8, 13-15. ISSN $0972-$ 0626.

126. Hajipour, A.; Mallakpour, S.; Imanzadeh, G. Indian J. Chem. 2001, 40B, 250-251. http://nopr.niscair.res.in/handle/123456789/22227

127. Mortoni, A.; Martinelli, M.; Piarulli, U.; Regalia, N.; Gagliardi, S. Tetrahedron Lett. 2004, 45, 6623-6627. https://doi.org/10.1016/j.tetlet.2004.07.026

128. Habibi, D.; Marvi, O. Arkivoc 2006 (xiii), 8-15. http://dx.doi.org/10.3998/ark.5550190.0007.d02

129. Chandrasekhar, S.; Takhi, M.; Uma, G. Tetrahedron Lett. 1997, 38, 8089-8092. http://dx.doi.org/10.1021/jo962202c

130. Chandrasekhar, S.; Padmaja, M. B.; Raza, A. Synlett 1999, 10, 1597-1599. http://dx.doi.org/10.1055/s-1999-2894

131. Lewis, D.; Summers, J.; Ward, T.; McGrath, J. J. Polym. Sci. A: Polym. Chem. 1992, 30, 1647-1653. http://dx.doi.org/10.1002/pola.1992.080300817

132. Martin, B.; Sekljic, H.; Chassaing, C. Org. Lett. 2003, 5, 1851-1853. http://pubs.acs.org/doi/10.1021/ol0343818

133. Isasmendi Escudero, M.; Kremenchuzky, L.; Perillo, I.; Cerecetto, H.; Blanco, M. Synthesis 2011, 4, 571576. https://doi.org/10.1055/s-0030-1258398

134. Sun, J.; Yan, C-G. Huaxue Yanjiu 2002, 13, 39-40. ISSN: 1008-1011.

135. Liu, X.; Qie, L.; Ma, Z.; Shan, J.; Shen S. Chem. J. Internet 2002, 4, 43. http://www.chemistrymag.org/cji/2002/049043ne.htm

136. Liu, X.; Ma, Z.; Shen, S.; Shan, J.; Du, B. Chem. J. Internet 2003, 5, 66. http://www.chemistrymag.org/cji/2003/058066ne.htm

137. Bogda, D.; Pielichowski, J.; Boro, A. Synlett 1996, 9, 873-874. http://dx.doi.org/10.1055/s-1996-5587

138. Hekmatshoar, R.; Heravi, M.; Baghernejad, B.; Asadolah, K. Phosphorus, Sulfur, Silicon 2004, $179,1611-$ 1614. http://dx.doi.org/10.1080/10426500490466157 


\section{Authors' Biographies}

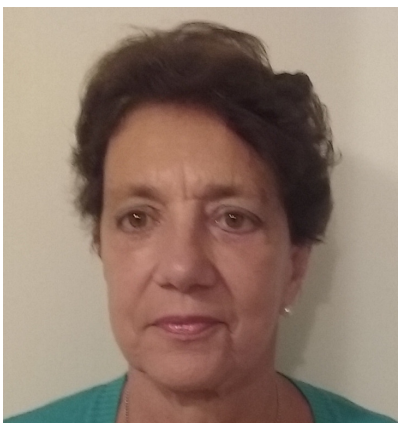

Prof. Dr. Isabel A. Perillo was born in Buenos Aires, Argentina, in 1942. She studied at the Buenos Aires University receiving degree in Biochemistry in 1965 and a PhD in Biochemistry under the supervision of Dr. Samuel Lamdan. Her research interests include organic and heterocyclic chemistry, particularly, the synthesis and chemical properties of nitrogen heterocyclic compounds. She has published about 100 research articles related with these subjects. Since 1976, she has worked at the School of Pharmacy and Biochemistry of the Buenos Aires University as Full Professor of Organic Chemistry. She is currently Active Emeritus Professor of Organic Chemistry at the Department of Organic Chemistry.

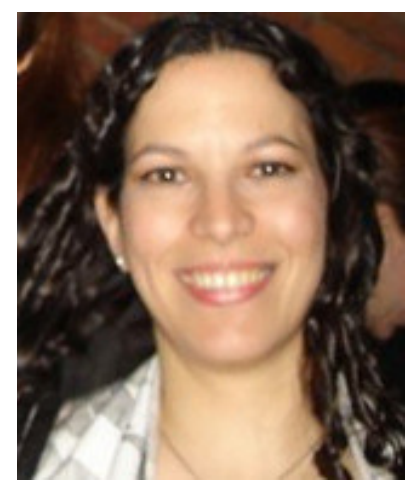

M. Sol Shmidt was born in Buenos Aires, Argentina in 1975. She received her degree in Pharmacy from University of Buenos Aires (2006). She obtained her Ph.D. degree at the same University, studying the synthesis of 3-hydroxy-4-quinolinone-2-carboxylic acid derivatives and substituted isatins, under the direction of Professors Dr Isabel A. Perillo and Dr M. Mercedes Blanco, successively. She is currently an assistant professor at the Organic Chemistry Department, School of Pharmacy and Biochemistry, University of Buenos Aires.

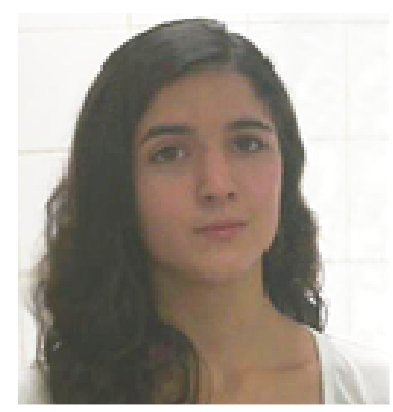

Sofía Prieto was born in Buenos Aires, Argentina in 1994. She studies the fourth year of the Pharmacy School at the University of Buenos Aires and collaborates in research tasks in the Organic Chemistry Department at the same Faculty. 


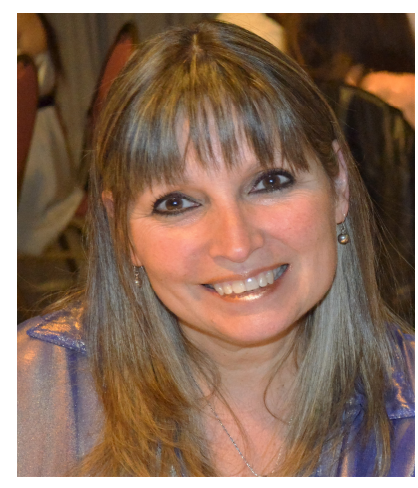

Prof. Dr. María M. Blanco was born in Buenos Aires, Argentina in 1962. She is Associate Professor at the Department of Organic Chemistry at the School of Pharmacy and Biochemistry (Buenos Aires University, Argentina). She received her degree in Biochemistry (1986) and Pharmacy (1993) at the Buenos Aires University. In 2004 she obtained the PhD degree at the same University under the supervision of the Dr. Isabel Perillo. Her research interest focuses on synthetic heterocyclic chemistry for medicinal applications. 